\title{
The Cochlear Implant in Action: Molecular Changes Induced in the Rat Central Auditory System
}

\author{
Robert-Benjamin Illing and Nicole Rosskothen-Kuhl \\ Neurobiological Research Laboratory, \\ Department of Otorhinolaryngology, \\ University of Freiburg \\ Germany
}

\section{Introduction}

\subsection{Hearing and learning}

Learning is the essence of life. Throughout evolution, all species learn to adapt to a particular environment. As a consequence, organs are formed and reformed, and cellular function extends to respond to a broadening spectrum of types of energy and chemical compounds and focuses on particular stimulus configurations to respond to them in ever subtler ways. In ontogeny, chemical and spatial orientation is essential for the cells of an embryo so that it can grow all parts at the right time and at the right location. Postnatally, the radius from which an organism needs to learn expands from itself to the world surrounding it. For mammals, there appear to be two distinctly different phases of learning from the environment: early in life, or approximately before sexual maturity, and later in life, or post puberty. It has been a remarkable neuroscientific discovery that the molecular machinery employed by organism during their development is subtly but effectively modified to provide neuroplasticity later in life.

We learn to hear in ontogeny beginning at prenatal times (Peña et al., 2003), and patients receiving a cochlear implant $(\mathrm{CI})$ need to learn or to re-learn hearing, depending on whether they never heard or they originally had a normal hearing experience. Both challenges require specific forms of learning. Learning implies appropriate adjustments of nervous networks to reflect differences and changes in patterns of sensory activity. Neuroscience looks for molecular, structural, and functional consequences of learning in the nervous system and refers to these changes as indicators of neuronal plasticity. To study sensoryevoked learning and plasticity we need to look at the molecular profile and cellular dynamic of neurons to identify its lasting traces in the brain.

One molecular marker associated to the initiation of sensory-evoked neuronal remodeling is the early response gene product c-Fos. Among the markers reflecting a growth-response of nerve cells and their synapses is the growth-associated protein GAP-43. 


\subsection{Auditory brainstem plasticity}

Although earlier reports already suggested the possibility of structural plasticity in the adult mammalian brainstem (Wall \& Egger, 1971; Pollin \& Albe-Fessard, 1979), this mode of learning remained largely unacceptable into the 1980s. However, evidence slowly began to accumulate that structural plasticity is a general phenomenon of the adult mammalian brain, including all ages and all levels of the cerebral hierarchy. Equally important was the discovery that adult plasticity reuses many molecular mechanisms and regulatory circuits on which embryogenesis relies. However, important differences exist between juvenile and adult brain plasticity with respect to speed, breadth, and type of changes inducible by internal or external stimuli (e.g. Harris et al., 2005; 2008). At all developmental stages, neuroplasticity has many facets and includes the mutability on virtually all levels of neuronal organization, including volume growth, modifications of topographical maps, axon rerouting, dendritic outgrowth or retraction, cell death, mitosis, synaptogenesis, and molecular changes of various sorts. We finally appreciate the brain as an instrument of change.

\section{3 c-Fos}

\subsection{1 c-Fos and learning}

Immediate early genes are essential actors mediating learning-associated cellular processes and neuroplasticity. Although the immediate early gene product c-Fos has, together with phosphorylated extracellular signal-related kinase (p-ERK), been used as a marker for central sensitization, particularly in studies using nociception (Gao \& Ji, 2009), its expression signifies not just electrophysiological activity but also cellular activity on different levels. Expression of c-Fos, like other early response genes, links fleeting changes of neuronal activity to lasting modifications of structure and function in the mammalian nervous system. Zuschratter et al. (1995) compared the spatial distribution of c-Fos immunoreactive neurons with the density of 2-desoxy-D-glucose (2DG) autoradiography after $1 \mathrm{~h}$ of acoustic stimulation. While the pattern of the highest density of c-Fos labeled cells in the auditory cortex matched the peak labeling of autoradiographs, a spreading of c-Fos expression in neurons across the tonotopic maps was observed in primary auditory cortex and in the rostral and caudal fields of the auditory cortex. Corresponding to its role beyond indicating electrophysiological activity, c-Fos has been reported to be involved in the learning correlate of long term potentiation (Racaniello et al., 2010). Watanabe et al. (1996) found that homozygous mice carrying a null mutation of $c$-fos fail to show much of functional and structural plasticity seen in normal mice.

Auditory cortical neurons were shown to turn c-Fos positive following behaviorally significant sounds (Fichtel \& Ehret, 1999; Wan et al., 2001; Geissler \& Ehret, 2004). Sound recognition was compared with perception of exactly the same sound in mice. They showed that sound recognition, relying on memory, entails less but well focused Fos-positive cells in a primary auditory cortical field and significantly more labeling in higher order fields.

\subsubsection{Regulation of C-Fos}

The immediate early gene $c$-fos has, as part of its promoter, a transcription factor binding site called the cAMP response element (CRE; Ginty et al., 1994; Gispen et al., 1991). Thus, glutamate binding on NMDA receptors may activate the $c-f o s$ gene in neurons through the 
calcium-dependent phosphorylation of the CRE binding protein CREB by ERK and/or CaMKIV kinase pathways. CREB phosphorylation is modulated in cochlear nucleus and superior olivary complex as a consequence of electrical stimulation in the cochlea (Illing \& Michler, 2001). Apart from CRE, the $c$-fos promoter contains a sis inducible element (SIE), a serum response element (SRE), and an activator protein-1 (AP-1)-like sequence (FAP) (Herdegen \& Leah, 1998.). Besides its acting on the $c$-fos promoter, p-CREB may also affect expression of other genes containing a CRE site. Among them are the genes coding for the brain derived neurotrophic factor BDNF (Tao et al., 1998; Xu et al., 2000) and the early growth response protein-1 (Egr-1) (Sakamoto et al., 1991; Schwachtgen et al., 2000), another immediate-early gene product which is also known as Krox-24, Zif268, Zenk, NGFI-A, and Tis8. Apart from its CRE site, the promoter of the Egr-1 gene contains a SRE site and an AP1 site (Schwachtgen et al., 2000; Weber \& Skene, 1998). Competing with the activating transcription factor-2 (ATF-2; van Dam \& Castellazzi, 2001), the protein c-Fos may dimerize with still another immediate-early gene product, c-Jun, to constitute a powerful transcription factor complex, called AP-1. The AP-1 factor, in turn, differentially triggers the expression of a large number of genes in a variety of functional aspects (Wisdom, 1999), with ATF-2:Jun and Fos:Jun complexes having differential binding preferences for heptameric or octameric AP-1 binding sites (van Dam and Castellazzi, 2001). Among the genes controlled by AP-1 are genes coding for the basic fibroblast growth factor bFGF (Shibata et al., 1991) and the growth and plasticity associated protein GAP-43 (Nedivi et al., 1992; Weber \& Skene, 1998). Deficiency in ATF-2, in turn, leads to neurodegeneration of subsets of somatic and visceral motorneurons of the brainstem (Ackermann et al., 2011). There are conditions under which c-Fos may appear in glial cells (Edling et al., 2007).

Looking further upstream of c-Fos expression, cellular growth factors come into focus (Sharpe et al., 1993; Ginty et al., 1994). Interestingly, p-CREB is involved in regulating BDNF transcription (Tao et al., 1998), which in turn binds to TrkB receptors, modulating synaptic long-term potentiation (Xu et al., 2000) and driving the expression of c-Fos and other early response genes.

Illustrating the richness of molecular changes due to manipulating sensory input, the expression of immediate early genes, among them egr-1 and $c-f o s$, and neuronal plasticityrelated genes such as those encoding for Arc, Syngr-1, and BDNF, was decreased by 2 weeks but increased again by 4 weeks in rat auditory cortex following bilateral cochlear ablation (Oh et al., 2007). ATF-2 is involved in the molecular underpinning of neuronal stability, cell death, and cellular growth (Yuan et al., 2009). Its expression goes down in retinal ganglion cells after their axotomy. Those cells capable of regrowing their axon show a return to high ATF-2 expression, indicating their return to normal conditions (Robinson GA, 1996). Members of the family of mitogen-activated protein kinases (MAPK) are ERK and p38 MAPK. ERK expression and phosphorylation reflects cellular changes associated to learning in an fear conditioning paradigm (Ota et al., 2010) and is co-regulated with c-Fos in several systems (Yang et al., 2008; Brami-Cherrier et al., 2009). Signals induced as a consequence of unilateral cochlear ablation are transduced mainly through the neuronal ERK pathway (Suneja \& Potashner, 2003).

According to data available in the literature, the half- life of c-fos mRNA is 10-15 min (Müller et al., 1984; Sheng and Greenberg, 1990), whereas the c-Fos protein has a half-life of around 2 h (Curran et al., 1984; Müller et al., 1984). 


\subsubsection{Sensory stimulation of the auditory pathway}

Sound-induced c-Fos expression has been employed to investigate the functional anatomy of the central auditory system of the mammalian brain. Expression of c-Fos has been seen in central auditory neurons after acoustical or electrical stimulation of the ear. Using pure-tone stimulation of mice or rats, the locations of neurons that turn positive for c-Fos or its mRNA were found to match the electrophysiologically established tonotopic maps in the ventral and dorsal cochlear nucleus (Rouiller et al., 1992; Brown \& Liu, 1995; Miko et al., 2007), the superior olive (Adams, 1995), the dorsal nucleus of the lateral lemniscus (Saint Marie et al., 1999A), the inferior colliculus (Ehret \& Fischer, 1991; Friauf, 1995; Pierson \& Snyder-Keller, 1994; Saint Marie et al., 1999B), and the auditory cortex (Zuschratter et al., 1995). It was also induced in the vestibular nuclei (Sato et al., 1993). On exposing rats to specific behavioral tasks dependent on auditory stimuli, expression of c-Fos was also found in auditory centers of the diencephalon and telencephalon (Campeau \& Watson, 1997; Carretta et al., 1999; Scheich \& Zuschratter, 1995).

The amount of c-Fos mRNA also reflects habituation following stressful auditory stimulation (Campeau et al., 2002). Expression of c-Fos has also been used to estimate the driving force of axonal projections inside the central auditory system (Sun et al., 2009; Clarkson et al., 2010) and to localize the target site of audiogenic seizure (Kai \& Niki, 2002) or the origin of tinnitusrelated over-activity ( $\mathrm{Wu}$ et al., 2003). The neuronal response reflected by c-Fos expression is related to the selective response of different subpopulations of neurons to sounds of timevarying properties ( $\mathrm{Lu}$ et al., 2009) and may be induced by disinhibition following nerve lesions (Luo et al., 1999). The precision of a tonotopic c-Fos response to pure tone stimulation appears to be under the control of EphA4 and ephrin-B2 (Miko et al., 2007).

\subsubsection{Electrical stimulation of the auditory pathway}

Electrical intracochlear stimulation (EIS) as done with CIs in humans was shown to be similarly effective as acoustical stimulation in driving cells to express c-Fos (Roullier et al., 1992; Illing \& Michler, 2001; Nakamura et al., 2003). Subsequent studies showed a marked variability in the pattern of stimulation-dependent c-Fos expression in the auditory brainstem. Some studies reported massive induction of c-Fos in dorsal cochlear nucleus (DCN), with little expression in ventral cochlear nucleus (VCN), and a substantial increase of c-Fos immunoreactivity in the external nuclei of the inferior colliculus (IC), with little staining in its central nucleus CIC (Vischer et al., 1994; 1995; Zhang et al., 1996). Others reported distinctly different patterns of c-Fos expression upon EIS (Illing \& Michler, 2001; Saint Marie et al., 1999A, 1999B; Saito et al., 1999; Zhang et al., 1998). In several studies involving electrical stimulation, tonotopic patterns of c-Fos expression were found (Saito et al., 1999; Nagase et al., 2000; Saito et al., 2000; Illing \& Michler, 2001), but others did not report it (Nakamura et al., 2005). c-Fos has also been induced after neonatal auditory deprivation (Keilmann \& Herdegen, 1995; 1997) and in kanamycin-deafened rats (Fujii et al., 1997; Nagase et al., 2003). Like EIS, directly stimulating the dorsal cochlear nucleus is effective in driving tonotopic c-Fos expression (Takagi et al., 2004) and produces hearing in rats (Zhang \& Zhang, 2010).

\subsection{GAP-43}

In pre- and early postnatal development of the mammalian brain, expression of the membrane phosphoprotein GAP-43, also known as B-50, F1, pp46, P-57, or neuromodulin, is 
high in neuronal somata, axons, and growth cones (Gispen et al., 1991; Kinney et al., 1993). Brain areas known for their adult potential for plasticity are characterized by high levels of GAP-43 (Benowitz et al., 1988; Benowitz and Routtenberg, 1997). This protein is a neuronspecific calmodulin-binding phosphoprotein and substrate for protein kinase C (Gispen et al., 1991; Schaechter \& Benowitz, 1993). There are several lines of evidence relating this protein to axonal growth as well as to plasticity. It is produced at high levels in every nerve cell during neurite outgrowth and early stages of synaptogenesis (Skene and Willard, 1981; Mahalik et al., 1992) and represents a major constituent of the isolated growth cone (De Graan et al., 1985; Meiri et al., 1998). With maturation, its expression is down-regulated by most neurons (Skene, 1989; Benowitz \& Perrone-Bizzozero, 1991). When a sense construct of GAP-43 mRNA was transiently expressed in non-neuronal cultured cells, these cells grow filopodial-like processes (Yankner et al., 1990; Verhaagen et al., 1994). If cells were transfected with a mutated construct of GAP- 43 which prevented attachment of GAP-43 into the cell membrane, GAP-43 did not accumulate in pseudopods and no changes in cell morphology were induced (Widmer \& Caroni, 1993). The attenuation of endogenous GAP-43 by an antibody that was raised against this protein and injected intracellularly has been found to reduce the degree of neurite outgrowth in a dose-dependent manner (Shea et al., 1992). The over-expression of GAP-43 in transgenic mice results in the formation of additional and aberrant neuronal connections (Aigner et al., 1995). Conversely, a knock out of the GAP-43 gene is survived by only $5-10 \%$ beyond weaning (Strittmatter et al., 1995). Whereas GAP-43 (-/-) mice show significant impairments in muscle strength, limb coordination and balance, and exhibit hyperactivity and reduced anxiety, GAP-43 (+/-) mice are only moderately impaired as compared with wild-type animals (Metz \& Schwab, 2004). However, significant memory deficits were reported of heterozygous GAP-43 knockout mice with GAP-43 levels reduced by one-half, providing further evidence that GAP-43 exerts a crucial role in the bidirectional regulation of mnemonic processing (Rekart et al., 2005).

Expression of GAP-43 runs, at least partially, over activation of an AP-1 binding site. This identifies GAP-43 as a potential gene influenced by c-Fos. Further upstream, cooperation between p75(NTR) and TrkA results in an increased NGF-mediated TrkA autophosphorylation (Diolaiti et al., 2007). This cooperation also leads to a sustained activation of ERK-1/2 by phosphorylation and accelerates neurite outgrowth concomitant with a selective enhancement of the AP-1 activity and the transcriptional activation of genes such as GAP-43.

We discovered that unilateral deafness inflicted by a total sensory deafferentation of the cochlear nucleus in the mature rat invokes expression of GAP-43 (Illing \& Horváth, 1995; Illing et al., 1997; see also Gil-Loyzaga et al., 2010). Since then, we found that this GAP-43 resides in presynaptic endings (Hildebrandt et al., 2011), is expressed by cholinergic neurons (Meidinger et al., 2006) residing in the ventral nucleus of the trapezoid body (Kraus \& Illing, 2004), and innervate only specific subtypes of neurons in the cochlear nucleus (Illing et al., 2005). Altogether, these results clearly indicate that sensory deafferentation is followed by a specific reorganization of the neuronal network in the cochlear nucleus. Realizing that there is an impressive potential of neuroplasticity in the adult mammalian brainstem we wondered if other modifications of the pattern of sensory-evoked neuronal activity might be answered by a comparable response of the auditory brainstem in terms of synaptic reorganization and, as a consequence, signal representation and analysis. We therefore turned to EIS. 


\subsection{Linking c-Fos with GAP-43}

Much is known about molecular networks regulating cellular growth and differentiation processes in general, but we still know little about the organization of the switch stands of activity-dependent molecular regulation in vivo. Regulatory molecules preceding c-Fos expression include p-CREB, p-ERK-1/2, p38 MAPK, and p-ATF-2. Molecules whose expression may be influenced by c-Fos include GAP-43, neuroskeletal elements, and cell adhesion molecules (Illing, 2001).

Williams et al. (1991) already suggested that an early response to sciatic nerve injury consisting of c-Fos expression in the spinal cord is transformed into a GAP-43 response emerging in the same spinal region of Rexed's lamina II, if not the same cells. It remained open if axonal sprouting mediated by GAP-43 is beneficial to the lesioned systems or accounts for sensory disorders following nerve injury (Woolf et al., 1990).

Demonstrating a succession of c-Fos and GAP-43 in functional states of neurons related to activity-dependent modifications of brain structure more directly, Kleim et al. (1996) showed that the number of synapses per neuron and the percentage of Fos-positive cells within motor cortex was elevated in rats raised in conditions requiring acrobatic motor activity as compared to rats raised without such requirement. Their data suggest that Fos may be involved in the biochemical processes underlying skill acquisition and that motor learning, as opposed to motor activity, leads to increases in synapse number in the motor cortex. Correspondingly, Black et al. (1990) see a relation between c-Fos expression and synaptogenesis, and synaptogenesis, in turn, relies on the presence and action of GAP-43 (Benowitz \& Routenberg, 1997). Diets improving spatial cognition of rats concomitantly raise the number of c-Fos positive neurons in hippocampus, resulting in a statistically significant negative correlation between the number of c-Fos positive neurons and the frequency of reference memory errors (Tanabe et al., 2004).

Watanabe et al. (1996) used a kindling model of epilepsy in which changes of neuronal activity in the form of brief focal seizures lead to lifelong structural and functional reorganization of the mammalian brain (McNamara et al., 1993). Brains thus affected by patterns of activity deviating from the normal develop axonal sprouting in hippocampal granule cells. However, when c-Fos was made unavailable for these brains due to a nullmutation, axonal sprouting is strongly reduced. Their data are consistent with the hypothesis that the lack of c-Fos reduces functional plasticity as well as a structural plasticity. This study again supports the hypothesis that the absence of c-Fos leads to a substantial attenuation of axonal plasticity due to a failure to activate growth-related genes such as GAP-43.

As a consequence of BDNF binding on the TrkB receptor, the expression of both c-Fos and GAP-43 is modulated (Edsjö et al., 2001; Koponen et al., 2004). Another feature shared by cFos mRNA and GAP-43 mRNA is to be stabilized by the same protein HuD (Chung et al., 1996; Mobarak et al., 2000; Smith et al., 2004). Binding of HuD apparently leads to increased levels of the respective protein under constant transcriptional conditions. This opens the possibility that c-Fos and GAP-43 share part of the regulation controlling their presence and availability, a feature that deserves attention in future research. 


\section{Methods}

\subsection{Animals}

The region of the brain in which we looked for stimulation-dependent changes on the molecular and cellular level is the rat auditory brainstem. Wistar rats of either sex aged 6 to 12 weeks were used. Care and use of the animals as reported here were approved by the appropriate agency (Regierungspräsidium Freiburg, permission number 37/9185.81/G10/83). Rats were anesthetized with a mixture of ketamin (i.p., $50 \mathrm{mg} / \mathrm{kg}$ body weight; BelaPharm GmbH \& Co. KG, Vechta, Germany) and xylazine (i.p., $5 \mathrm{mg} / \mathrm{kg}$ body weight; Rompun, Bayer-Leverkusen, Germany) before auditory brainstem response (ABR) measurements were done. For experiments involving acute EIS, anesthesia was induced by urethane (i.p., $1.5 \mathrm{~g} / \mathrm{kg}$ body weight; Fluka AG, Buchs, Schwitzerland).

\subsection{Deafness model}

Between postnatal day (P) 10 and P20 (inclusive), neonatal Wistar rats received daily injections of kanamycin (i.p., $400 \mathrm{mg} / \mathrm{kg}$ body weight; Sigma, Taufkirchen, Germany) (Fig. 1). Due to hair cell destruction caused by this antibiotic (Matsuda et al., 1999; Osaka et al., 1979), a rise of hearing threshold was seen against normal hearing rats when rats have grown to adulthood (Fig. 2 A, B).

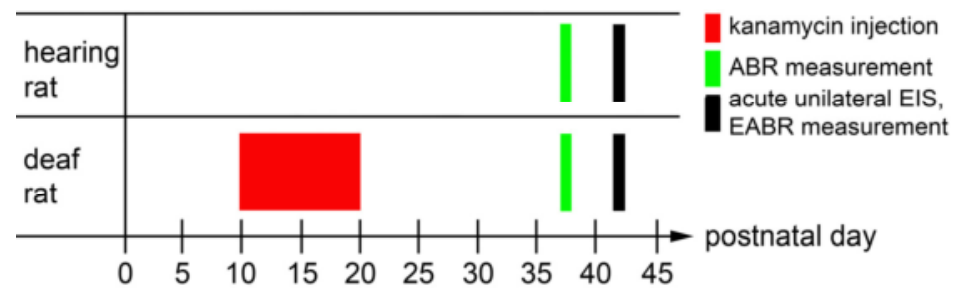

Fig. 1. Protocol to establish hearing and deaf experimental groups. Neonatal deafness was induced by daily kanamycin treatment between postnatal days 10 to 20 . Measurement of acoustically or electrically evoked brainstem responses (ABR/EABR) were made around P33 and P42, respectively.

\subsection{Electrical Intracochlear Stimulation (EIS)}

Brains of hearing-experienced and hearing-inexperienced rats were analyzed after EIS lasting for different times, with stimulation durations spaced by the factor of 1.6: $45 \mathrm{~min}$, $73 \mathrm{~min}, 2 \mathrm{~h}, 3: 15 \mathrm{~h}$, and $5 \mathrm{~h}$ (Fig. $2 \mathrm{C}, \mathrm{D})$. The electrode used was a CI connected to a communicator both kindly provided by Cochlear $\mathrm{GmbH}$ (Hannover, Germany). Bipolar stimulation consisted of $50 \mathrm{~Hz}$ biphasic stimuli with a phase width of $50 \mu \mathrm{s}$. The electrically evoked brainstem response (EABR) was recorded like the ABR (see below) to determine an appropriate current level. The EABR was visualized using an averager (Multiliner E; Evolution 1.70c), calculating mean amplitudes over 500 sweeps in a frequency band of 0.1 to $10 \mathrm{kHz}$. We aimed to obtain maximal EABR amplitudes of $10 \mu \mathrm{V} \pm 10 \%$ by adjusting the current level of EIS to match acoustic stimuli of about $75 \mathrm{~dB}$ SPL. Chronic stimulation in the awake rat was done with the same mode using the same electrodes, but implants were connected to the stimulator by way of a swivel and a skull-based interface. 


\subsection{Auditory and electrically evoked brainstem responses}

ABRs and EABRs were measured for hearing-experienced and hearing inexperienced rats. Hearing thresholds were tested acoustically (ABR) and electrically (EABR) by inducing auditory brainstem responses (Fig. 2 A, B). For ABR recording, steel needle electrodes were placed subcutaneously at vertex and mastoids and a $20 \mathrm{~Hz}$ train of click stimuli was presented to one side through a brass pipe equipped with a conical plastic tip into the ear canal, while sensations through the other ear were masked by supplying white noise at the same sound pressure level. Sound pressure was stepwise increased, attempting to elicit an ABR visualized by an averager (Multiliner E; Evolution 1.70c; Toennies, Germany). ABR mean amplitudes were determined after 300 sweeps in a frequency band of 0.1 to $3 \mathrm{kHz}$. If a kanamycin-treated rat showed an $\mathrm{ABR}$ at a sound pressure level smaller than $95 \mathrm{~dB}$, recordings were stopped to avoid inducing further sensory stimulation. Following kanamycin treatment, we found ABR thresholds elevated by $75 \mathrm{~dB}$ to above $95 \mathrm{~dB}$. These rats consistently failed to show a motor response to a handclap (Preyer's reflex). The absence of Preyer's reflex was taken by Jero et al. (2001) as indicating a rise of ABR threshold beyond $81 \mathrm{~dB}$ SPL. This result served as an additionally indication of deafness caused in the kanamycin-treated group.
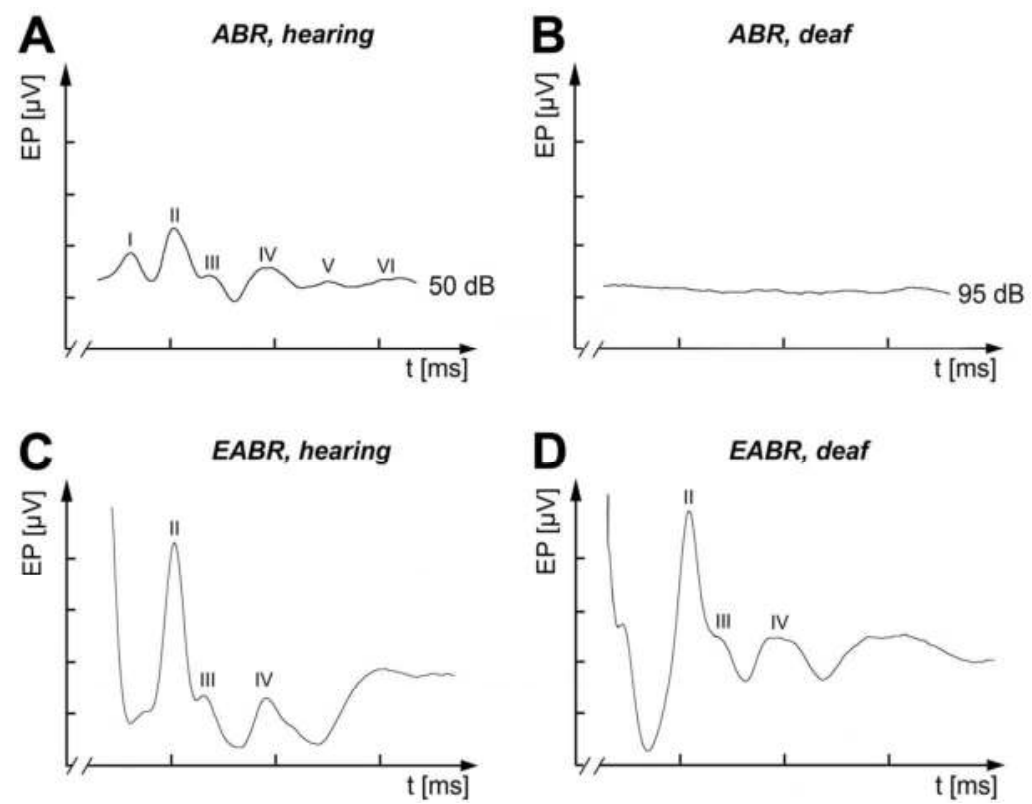

Fig. 2. $A B R$ and $E A B R$ in hearing and deaf rats. Representative acoustically $(A, B)$ and electrically $(C, D)$ evoked auditory brainstem responses of hearing $(A, C)$ and deaf $(B, D)$ mature rats. Typically, the ABR of a hearing rat showed six distinguishable peaks (I-VI) and the EABR at least three peaks (II-IV). No ABR was detectable in kanamycin-treated rats up to $95 \mathrm{~dB}$ SPL. $\mathrm{X}$-axis: $1 \mathrm{~ms}$ per unit; Y-axis: $4 \mu \mathrm{V}$ per unit; EP: evoked potential.

We localized c-Fos and GAP-43 by several variants of immunocytochemistry and in situ hybridization. Other antigens (p-ATF-2, c-Jun p39, p38 MAPK) were detected by 
immunocytochemistry based on diaminobenzidine staining or immunfluorescence (cp. Illing \& Michler, 2001; Rosskothen et al., 2008; Rosskothen-Kuhl \& Illing, 2010).

\subsection{Immunohistochemistry (IHC)}

After completion of the postoperative survival time or different stimulation periods, animals were killed by sodium-thiopental (i.p., $50 \mathrm{mg} / \mathrm{ml}$ per $200 \mathrm{~g}$ body weight of Trapanal $2.5 \mathrm{~g}$, Nycomed, Konstanz, Germany) and perfused transcardially with a fixative containing $4 \%$ paraformaldehyd and $0 \%-0.025 \%$ glutaraldehyde in $0.1 \mathrm{M}$ phosphate buffer at $\mathrm{pH} 7.4$. After brains were removed from the skulls and soaked in $30 \%$ sucrose overnight, parts containing anteroventral cochlear nucleus (AVCN), DCN, lateral superior olivary complex (LSO), and CIC were cryo-cut into $30 \mu \mathrm{m}$ thick frontal sections. Following incubation with $0.05 \% \mathrm{H}_{2} \mathrm{O}_{2}, 1 \%$ sodium-borohydride (only for c-Fos and p-ATF-2) and 1\% milk powder in $0.02 \mathrm{M}$ phosphate buffer saline (PBS) at $\mathrm{pH} 7.4$ for $30 \mathrm{~min}$ each, sections were exposed to a primary antibody either raised in goat against c-Fos (SC-52-G, 1:2000, lot. no. A2810, Santa Cruz Biotechnology Inc., Santa Cruz, USA), or raised in mouse against GAP-43 (MAB347, 1:5000, lot. no. LV1786431, Millipore, California, USA), or raised in rabbit against c-Jun p39 (SC-1694, 1:100-1:500; lot. no. L0606, Santa Cruz Biotechnology Inc.), p38 MAPK (4511S, 1:2000, lot. no. 5, Cell Signaling Technology, Inc., Danvers, USA), p-ATF-2 (5112S, 1:2000, lot. no. 10, Cell Signaling Technology, Inc.) or p-ERK 1/2 (SC-16982, 1:1000, lot. no. K1910, Santa Cruz Biotechnology Inc). After incubation for $48 \mathrm{~h}$ at $4^{\circ} \mathrm{C}$, visualization of antibody-binding sites was based on DAB staining using biotinylated anti-goat/-mouse/-rabbit (BA5000/BA2001/BA1000, 1:200, Vector Laboratories, Inc., Burlingame, USA) as secondary antibody and avidin-biotin-technique (Vector Laboratories) for signal intensification. Negative controls were run to verify specificity of the primary and secondary antibodies. Nuclei of the parabrachial region stained for c-Fos immunoreactivity served as positive controls (Illing et al., 2002).

\subsection{In Situ Hybridization (ISH)}

Thirty micrometer thick cryo-cut frontal brain sections were collected in $2 \mathrm{x}$ standard saline citrate (SSC) buffer (Invitrogen, Life Technologies GmbH, Darmstadt, Germany). The sections were washed in 2x SSC buffer for $15 \mathrm{~min}$. Before pre-hybridization sections were pretreated in a 1:1 dilution of 2x SSC and hybridization buffer (50\% formamide, Carl Roth $\mathrm{GmbH}$, Karlsruhe, Germany), 4x SSC (Invitrogen), 10\% dextransulfate (Sigma, Taufkirchen, Germany), 1x Denhardt's solution (AMRESCO Inc., Ohio, USA), $250 \mu \mathrm{g} / \mathrm{ml}$ heat-denatured cod and herring sperm DNA (Roche Diagnostics GmbH, Mannheim, Germany), $625 \mu \mathrm{g} / \mathrm{ml}$ tRNA from E. coli MRE 600 (Roche)) for $15 \mathrm{~min}$. Pre-hybridization lasted in hybridization buffer for $60 \mathrm{~min}$ at $55^{\circ} \mathrm{C}$. Hybridization was performed overnight at $55^{\circ} \mathrm{C}$ in the same solution with the addition of $100 \mathrm{ng} / \mathrm{ml}$ digoxigenin (DIG)-labeled c-Fos and $1000 \mathrm{ng} / \mathrm{ml}$ DIG-labeled GAP-43 antisense or sense cRNA, respectively. DIG-labeled sense and antisense cRNAs were synthesized by PCR amplification of brain tissue isolated c-Fos/GAP-43 mRNA. Primer design occurred by the use of the NCBI sequences NM_017195.3 (for GAP43) and NM_022197.2 (for c-Fos). After hybridization, the sections were washed in 2x SSC for $2 \times 15$ minutes at room temperature, 2x SSC and 50\% formamide (MERCK KGAA, Darmstadt, Germany) for $15 \mathrm{~min}, 0.1 \times$ SSC and 50\% formamide for $15 \mathrm{~min}$, and $0.1 \times$ SSC for $2 \times 15$ minutes at $65^{\circ} \mathrm{C}$ each. For immunological detection of DIG-labeled hybrids, brain 
sections were treated in buffer $1(100 \mathrm{mM}$ Tris/ $\mathrm{HCl}, \mathrm{pH} 7.5)$ for 2 × $10 \mathrm{~min}$ each, blocked in buffer 2 (1\% blocking reagent (Roche) in buffer 1) for $60 \mathrm{~min}$ at room temperature, and incubated overnight at $4^{\circ} \mathrm{C}$ with the anti-DIG Fab fragment from sheep tagged with alkaline phosphatase (1:1500, Roche) in buffer 2. For the color reaction, brain sections were equilibrated in buffer 1 for $2 \times 10$ min each and in buffer $3(100 \mathrm{mM}$ Tris/ $\mathrm{HCl}, \mathrm{pH}$ 9.5, 100 $\mathrm{mM} \mathrm{NaCl}, 50 \mathrm{mM} \mathrm{MgCl} 2)$ for $10 \mathrm{~min}$ before the addition of nitroblue tetrazolium $(0.34$ $\mathrm{mg} / \mathrm{ml}$, Roche) and 5-bromo-4-chloro-3-indolyl-phosphate, 4-toluidine salt $(0.17 \mathrm{mg} / \mathrm{ml}$, Roche) diluted in buffer 3. Development of the color reaction was performed for around 9 hours in the dark at room temperature and stopped by transfer into aqua when the desired staining intensity was reached. Finally, sections were mounted on glass slides, dehydrated in increasing grades of alcohol, cleared in xylene, and coverslipped with DPX (Sigma).

\subsection{Electron microscopy}

After perfusion as described above, brains were postfixed in the same fixative for $2 \mathrm{~h}$ and stored overnight in PBS. Cutting was done on a microtome with vibrating blade (Leica VT 1000S, Bensheim, Germany) at $50 \mu \mathrm{m}$ and collected in PBS containing $0.05 \mathrm{M}$ glycine. Sections were permeabilized by a treatment with $5 \%$ and $10 \%$ dimethyl sulphoxide (DMSO), each for $10 \mathrm{~min}$, and $20 \mathrm{~min}$ in 20\% and 40\% DMSO, all in PBS. Following washing in PBS, tissue was successively exposed to $0.05 \% \mathrm{H}_{2} \mathrm{O}_{2}, 0.05 \%$ sodium-borohydride, and $5 \%$ normal rabbit or goat serum in PBS each for $30 \mathrm{~min}$, and incubated with antibodies raised against cFos (1:2000), p-ATF-2 (1:2000), or p-ERK-1/2 (1:1000). After incubation for $24 \mathrm{~h}$ at $4^{\circ} \mathrm{C}$, visualization of antibody-binding sites occurred as described before for the IHC protocol (see. 2.5). Afterward, brain sections were incubated with $0.1 \%$ osmium-tetroxide in $0.1 \mathrm{M}$ cacodylic acid buffer (pH 7.4), dehydrated in ethanol and embedded in EMbed-812 (Science Services, München, Germany).

\section{Results and discussion}

\subsection{Effectiveness of EIS to induce gene expression}

EIS is an effective way to activate neuronal networks in the central auditory system, including the induction of c-Fos expression throughout the brainstem of hearingexperienced rats (Fig. 3).

We monitored c-Fos expression on the transcriptional level by detecting c-Fos mRNA as well as on the translational level by c-Fos immunoreactivity (Illing et al., 1999). In both cases we detected staining in neuronal nuclei that closely matched in space and time (Fig. 4).

Attempting to understand the laws according to which neurons express c-Fos as a consequence of EIS we, first, identified the cell types in which c-Fos emerged. Following $2 \mathrm{~h}$ of EIS we found that only distinct subpopulations of neurons in VCN, DCN, LSO, and CIC express c-Fos (Reisch et al., 2007) (Fig.5). Whereas sub-populations of glutamatergic and glycinergic cells responded in all four regions, GABAergic neurons failed to do so except in marginal zones of AVCN and in DCN (but cp. Ishida et al., 2002). Combining immunocytochemistry with axonal tracing, neurons participating in major ascending pathways, commissural cells of VCN and certain types of neurons of the descending auditory system were seen to respond to EIS with early response gene expression. By contrast, principal LSO cells projecting to the contralateral CIC as well as collicular efferents of the DCN did not. 


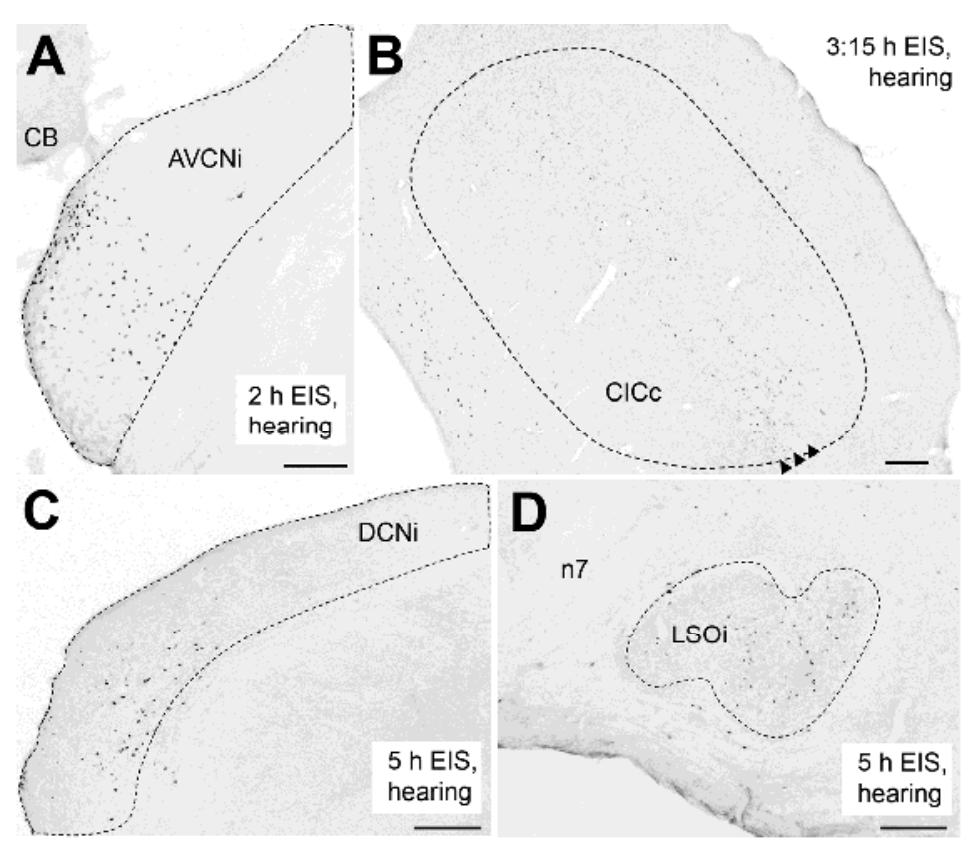

Fig. 3. Effectiveness of EIS to induce c-Fos expression throughout the brainstem of hearing rats. (A) Tonotopic c-Fos expression (black dots) in AVCNi after $2 \mathrm{~h}$ of EIS. (B) Tonotopic band (arrowheads) of c-Fos positive nuclei (black dots) in CICc after 3:15 h of EIS. (C) Tonotopic c-Fos expression (black dots) in the deep layers of DCNi after $5 \mathrm{~h}$ of EIS. (D) c-Fos expression (black dots) in LSOi following $5 \mathrm{~h}$ of sustained EIS. The dashed lines correspond to the borders of the respective auditory regions. Scale bars: $0.2 \mathrm{~mm}$. i: ipsilateral; c: contralateral; $\mathrm{CB}$ : cerebellum; n7: facial nerve.

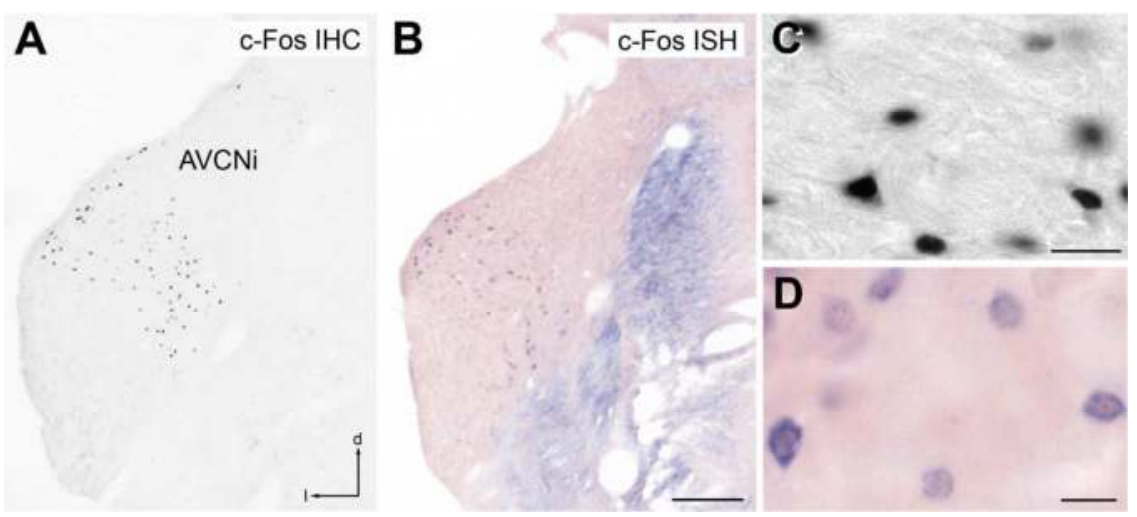

Fig. 4. Comparison of c-Fos immunoreactivity (A, C) vs. c-Fos in situ hybridization (B, D) in AVCNi of a hearing-experienced rat after 73 min EIS. (A, B) The pattern of c-Fos protein (black dots) and c-Fos mRNA (blue dots) of 2 adjacent sections is nearly identical. Scale bar: $0.2 \mathrm{~mm}$. (C, D) Higher magnification of c-Fos protein positive nuclei (C) and c-Fos mRNA positive neurons (D) in AVCNi. Scale bars: $20 \mu \mathrm{m}$. i: ipsilateral; d: dorsal; 1: lateral. 


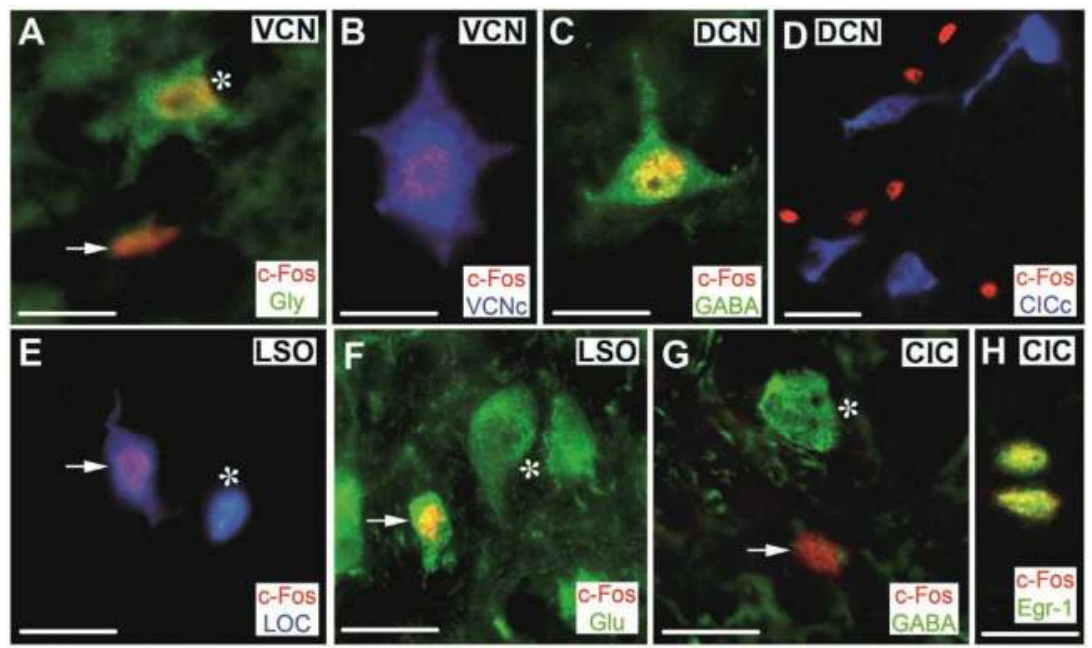

Fig. 5. EIS-dependent c-Fos expression in neurons of the auditory brainstem of hearingexperienced rats (Illing et al., 2010). (A) In VCN, half of the c-Fos positive nuclei were localized in glycinergic cells (Gly, yellow, asterisk), the other half showed no double labeling with glycine (arrow). (B) c-Fos in a large VCN commissural neuron after injection of the tracer Fast Blue into VCNc. (C) c-Fos in a GABAergic neuron of DCN. (D) c-Fos positive nuclei were never observed in neurons of DCN projecting to the contralateral CICc. (E) Some (arrow) but not all (asterisk) lateral olivocochlear (LOC) neurons labeled from the cochlea by axonal tracing showed co-localization with c-Fos. (F) c-Fos positive nuclei in small glutamatergic cells of LSOi (Glu, arrow), large glutamatergic cells lacked c-Fos immunoreactivity (asterisk). (G) CIC lacking c-Fos positive GABAergic cells. (H) Immunoreactivity for Egr-1 coincided with c-Fos immunoreactivity. i: ipsilateral, c: contralateral. Scale bars: $20 \mu \mathrm{m}$ in D, $10 \mu \mathrm{m}$ for all others.

Second, following continuous stimulation of hearing-experienced anesthetized rats for various durations from $45 \mathrm{~min}$ to 5 hours, we observed a non-linear increase of the population of c-Fos positive neurons, with a rise followed by a decline, followed by a second rise of the number of stained cells in VCN (Rosskothen-Kuhl \& Illing, 2010) (Fig. 6).

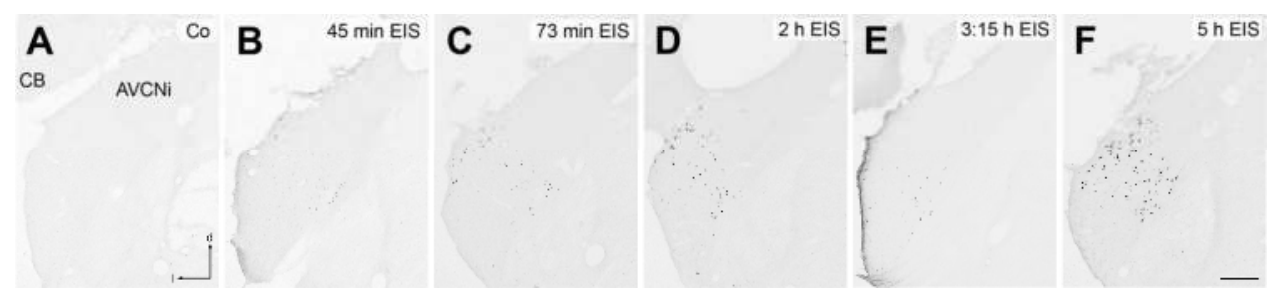

Fig. 6. Pattern of c-Fos expression with increasing stimulation time in AVCNi of hearingexperienced rats. (A) In control rats, AVCNi is devoid of c-Fos staining. (B-D) Typically, the number of c-Fos positive cells (black dots) increased from $45 \mathrm{~min}$ to $2 \mathrm{~h}$ in a region tonotopically corresponding to the stimulation position. (E-F) By 3:15 h of unilateral EIS, the c-Fos level transiently decreases before it rose again by $5 \mathrm{~h}(\mathrm{~F})$. Scale bar: $0.2 \mathrm{~mm}$. Co: control; i: ipsilateral; CB: cerebellum; d: dorsal; l: lateral. 
Third, we used different temporal patters known to have major significance for central auditory processing (Walton, 2010) for EIS at a constant duration of $2 \mathrm{~h}$ (Jakob \& Illing, 2008). For each of the major auditory brainstem nuclei and some of their subregions we found specific patterns of the immunoresponsive cell populations reflecting different aspects of the stimulation site and stimulation parameters (Table 1).

\begin{tabular}{|c|c|c|c|c|}
\hline & lateralization & intensity & frequency & duration \\
\hline AVCNi & + & + & 0 & + \\
\hline DCNi, upper layers & + & 0 & + & + \\
\hline DCNi, deep layers & + & 0 & + & + \\
\hline LSOi, medial & + & + & 0 & 0 \\
\hline LSOi, total & + & + & 0 & 0 \\
\hline CICc, dorsolat. & + & + & + & + \\
\hline CICc, ventromed. & + & + & + & 0 \\
\hline MGBc & 0 & + & 0 & 0 \\
\hline
\end{tabular}

Table 1. Expression pattern of c-Fos across the auditory brainstem depends on stimulation parameters. Each of the major auditory brainstem regions, and some of their subregions, showed a unique fingerprint of c-Fos expression (cp. rows) with respect to reflecting laterality, intensity, frequency (Jakob \& Illing, 2008), and duration of EIS. MGB: medial geniculate nucleus, i: ipsilateral, c: contralateral.

\subsection{Pharmacology}

Apart from the duration of EIS and the particular stimulation parameters used, the possibility exists that the consequences of activating the central auditory system may also be

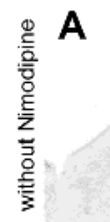

B

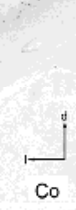

包

\section{A}

DCN

$E$

\section{$F$}

C

$1.6 \mathrm{~Hz}$

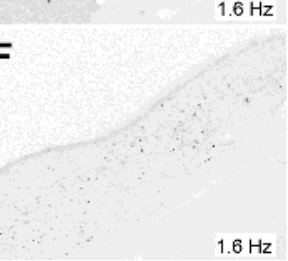

D

$50 \mathrm{~Hz}$

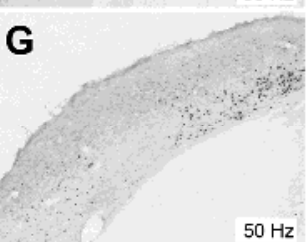

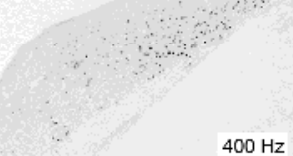

H

Fig. 7. Effect of Nimodipine on the pattern of c-Fos expression in the DCNi with different stimulation parameters. (B-D, F-H) For both experimental groups a shift of c-Fos positive nuclei (black dots) from the upper to the deep layers of DCN exist with increasing stimulation frequency, after $2 \mathrm{~h}$ of EIS. However, the Nimodipine treatment $(\mathrm{E}-\mathrm{H})$ resulted in a significant increase in number of c-Fos expressing neurons compared to non-treated (A-D) rats. Scale bar: $0.2 \mathrm{~mm}$. Co: control; i: ipsilateral; d: dorsal; l: lateral. 
influenced by pharmacological manipulations. Here we illustrate one example, the impact of Nimodipine systemically administered before EIS. In DCN, the pattern of neurons expressing c-Fos is dramatically different depending on the presence or absence of Nimodipine (Fig. 7).

\subsection{Molecules upstream of c-Fos expression}

In order to understand the functional relevance of c-Fos expression under any particular mode of stimulation, it is mandatory to co-localize it with other molecular actors of neuroplastic change in space and time. Therefore, we studied the spatio-temporal relationship of c-Fos expression with the expression pattern of molecules known to be involved directly or indirectly in the regulation of c-Fos expression. Upstream of c-Fos expression, p-CREB, ATF-2, p-ERK-1/2, and p38 MAPK unfold their activity. We discovered that their expression is modulated either positively or negatively under EIS (Fig. 8).

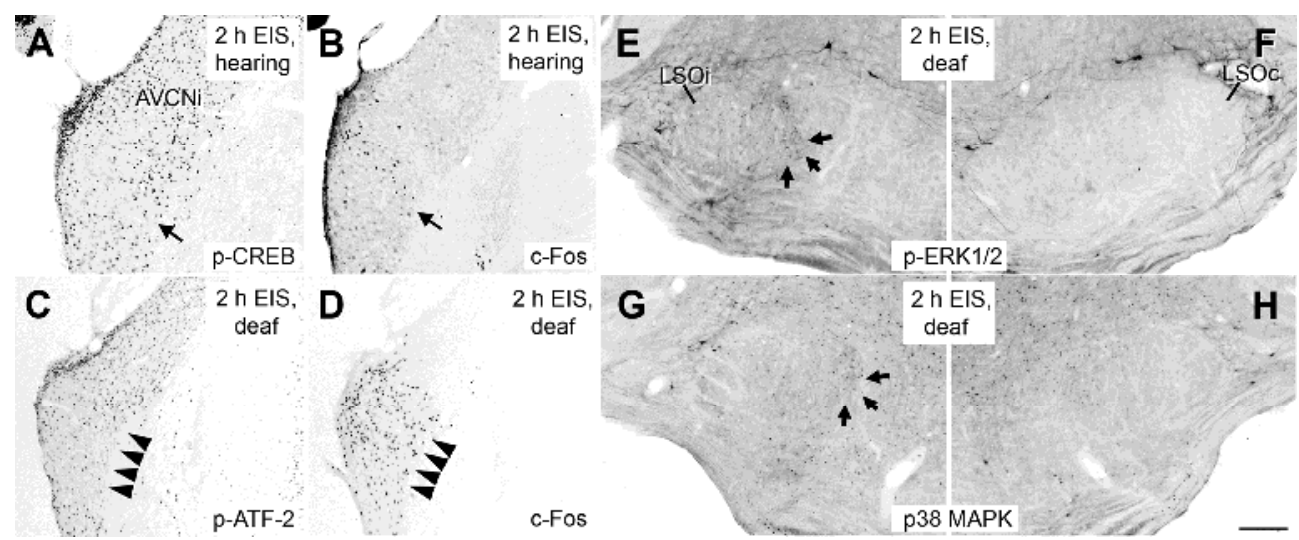

Fig. 8. Modulation of regulatory molecules upstream of c-Fos expression. (A-B) $2 \mathrm{~h}$ after EIS of hearing rats $\mathrm{p}$-CREB positive neurons were rare in a middle band of $\mathrm{AVCNi}(\mathrm{A}$, arrow) corresponding to the c-Fos positive area in the adjacent section (B, arrow). (C-D) A similar pattern existed for p-ATF-2 (C, arrowheads) and c-Fos (D, arrowheads) positive nuclei in the AVCNi of deaf rats after $2 \mathrm{~h}$ of EIS. (E-H) $2 \mathrm{~h}$ after EIS of deaf rats p-ERK-1/2 immunoreactivity was detected only in the LSO of the stimulated side (E, arrows) corresponding to the c-Fos expression pattern (not shown). Like for p-ERK-1/2 the p38 MAPK immunoreactivity was increased in the medial LSOi ( $G$, arrows) compared to the contralateral side $(\mathrm{H})$. c: contralateral; i: ipsilateral. Scale bar: $0.2 \mathrm{~mm}$.

Next, we looked for the ultrastructural localizations of molecules involved in the stimulation-dependent regulation of transcription factors (Fig. 9). Under EIS, c-Fos emerged in nuclei and rough endoplasmic reticulum of VCN neurons. p-ATF-2 and p-ERK-1/2 showed specific regional and intracellular staining patterns of their own.

Directly interacting with c-Fos is c-Jun p39. We found that, similar to the immediate early gene egr-1 (De et al., 2003) but unlike its stimulation-dependent expression in the inner ear (Ruan et al., 2007), c-Jun is present in most of the auditory brainstem in normal brains without specific stimulation (Fig. 10). Upon EIS and ensuing c-Fos expression, c-Fos and c-Jun may dimerize to form AP-1 in a highly active variant (Rosskothen et al., 2008) (Fig. 10 B-D). 


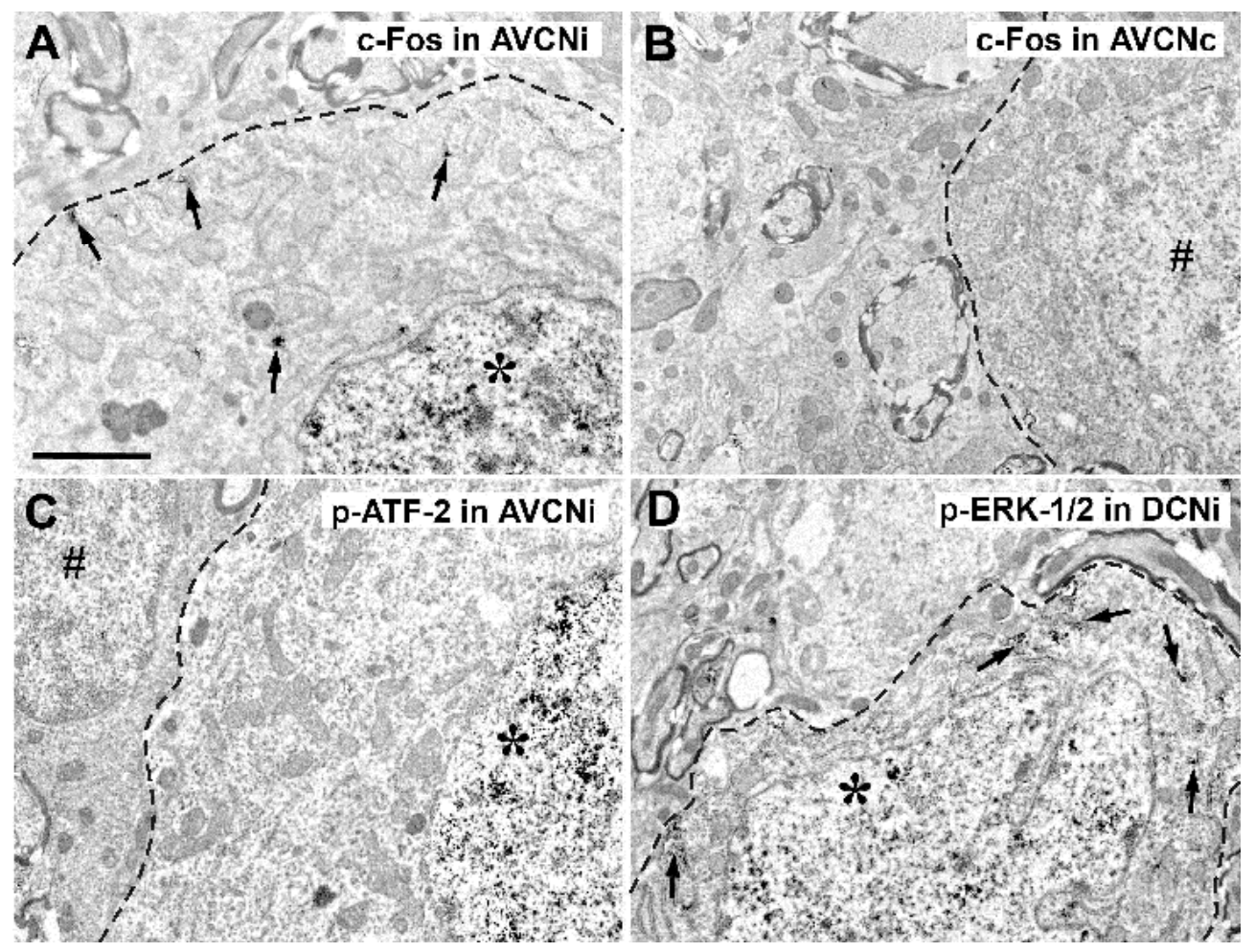

Fig. 9. Modulation of transcription factor regulators by EIS. (A) Ultrastructural localization of c-Fos immunoreactivity in nucleus (asterisk) and cytoplasm (arrows) of a neuron in AVCNi. (B) Contralaterally, no such staining was seen. (C) p-ATF-2 immunoreactivity in the nucleus of an AVCNi neuron; upon EIS, this staining declines. (D) p-ERK-1/2 staining in nucleus (asterisk) and cytoplasm (arrows) in a DCN neuron next to an unstained neuron after EIS. Dashed lines indicate cell boundaries. c: contralateral; i: ipsilateral. Scale bar: $2 \mu \mathrm{m}$.

\subsection{Molecules downstream of c-Fos expression}

Downstream of c-Fos lie many genes regulated by an AP-1 binding site in their promoter, among them the gene encoding GAP-43. We observed an emergence of GAP-43 in fibers and boutons of VCN on the side of chronic EIS (Fig. 11). At the same time, GAP-43 mRNA is strongly up-regulated in neurons of LSO (Fig. $11 \mathrm{C}-\mathrm{F})$.

The LSO is known to be involved in relearning sound localization during unilateral conductive hearing loss (Irving et al., 2011), suggesting that its neurons receive a growth signal by unilateral EIS that, in turn, causes axonal sprouting in VCN on the stimulated side. This scenario poses a remarkable contrast to GAP-43 expression in VCN one week after its total sensory deafferentation by cochlear ablation (Illing et al., 1997). Under these circumstances, GAP-43 in VCN is supplied by neurons of the ventral nucleus of the trapezoid body (VNTB), source of the medial olivocochlear pathway, rather than of LSO, source of the lateral olivocochlear pathway. 

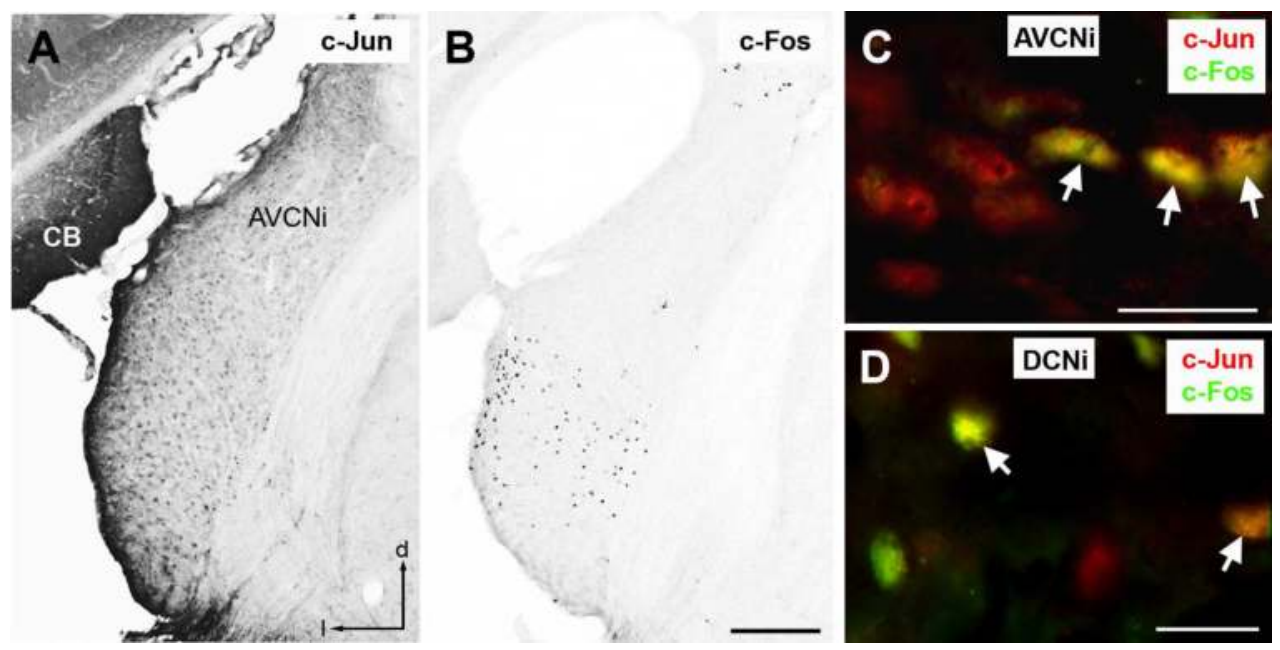

Fig. 10. The molecular environment of c-Fos expression includes the availability of c-Jun p39. (A) Numerous c-Jun positive nuclei (black dots) in the entire AVCNi of an unstimulated, hearing control rat. (B) c-Fos positive nuclei appear after EIS in a band corresponding tonotopically to intracochlear stimulation site. Scale bar: $0.2 \mathrm{~mm}$. (C, D) Following EIS, c-Fos (green) and c-Jun (red) are co-expressed (yellow/orange, arrows) in some but not all cells of AVCNi (C) and DCNi (D). i: ipsilateral; CB: cerebellum; d: dorsal; l: lateral. Scale bars: $20 \mu \mathrm{m}$.

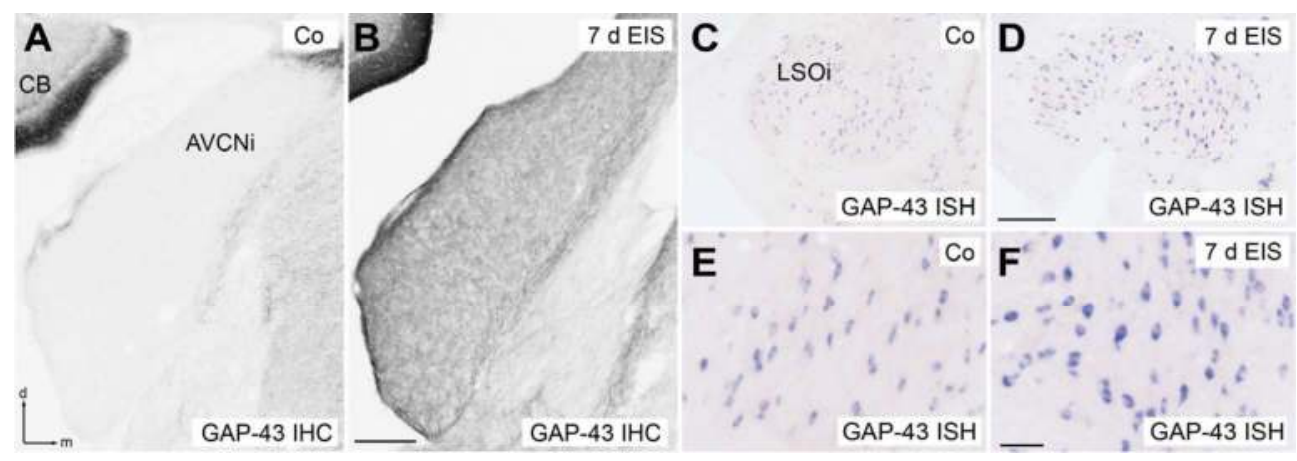

Fig. 11. Emergence of GAP-43 in the AVCNi after chronic EIS for 7 days. (A) AVCNi of a hearing control rat devoid of GAP-43 immunoreactivity. (B) GAP-43 immunoreactivity appears in the entire AVCNi of a 7 days $(7 \mathrm{~d})$ chronically stimulated hearing rat. (C-D) GAP43 mRNA level in the LSOi of a hearing control rat (C) and a 7 days stimulated hearing rat (D). Scale bars (A-D): $0.2 \mathrm{~mm}$. (E-F) GAP-43 mRNA in neurons of the LSOi at higher magnification. Scale bar: $50 \mu \mathrm{m}$. CB: cerebellum; Co: control; i: ipsilateral; d: dorsal; m: medial.

\subsection{EIS induces c-Fos expression in deaf rats}

The absence of hearing experience has far-reaching consequences for the interneuronal communication within networks of the auditory brainstem. First, when hearing fails, EIS 
entails expression of c-Fos in populations of neurons that are much larger than normally, essentially disregard tonotopic order, and lack much of spatio-temporal variations as seen in hearing-experienced rats (Rosskothen-Kuhl \& Illing, 2012) (Fig. 12).

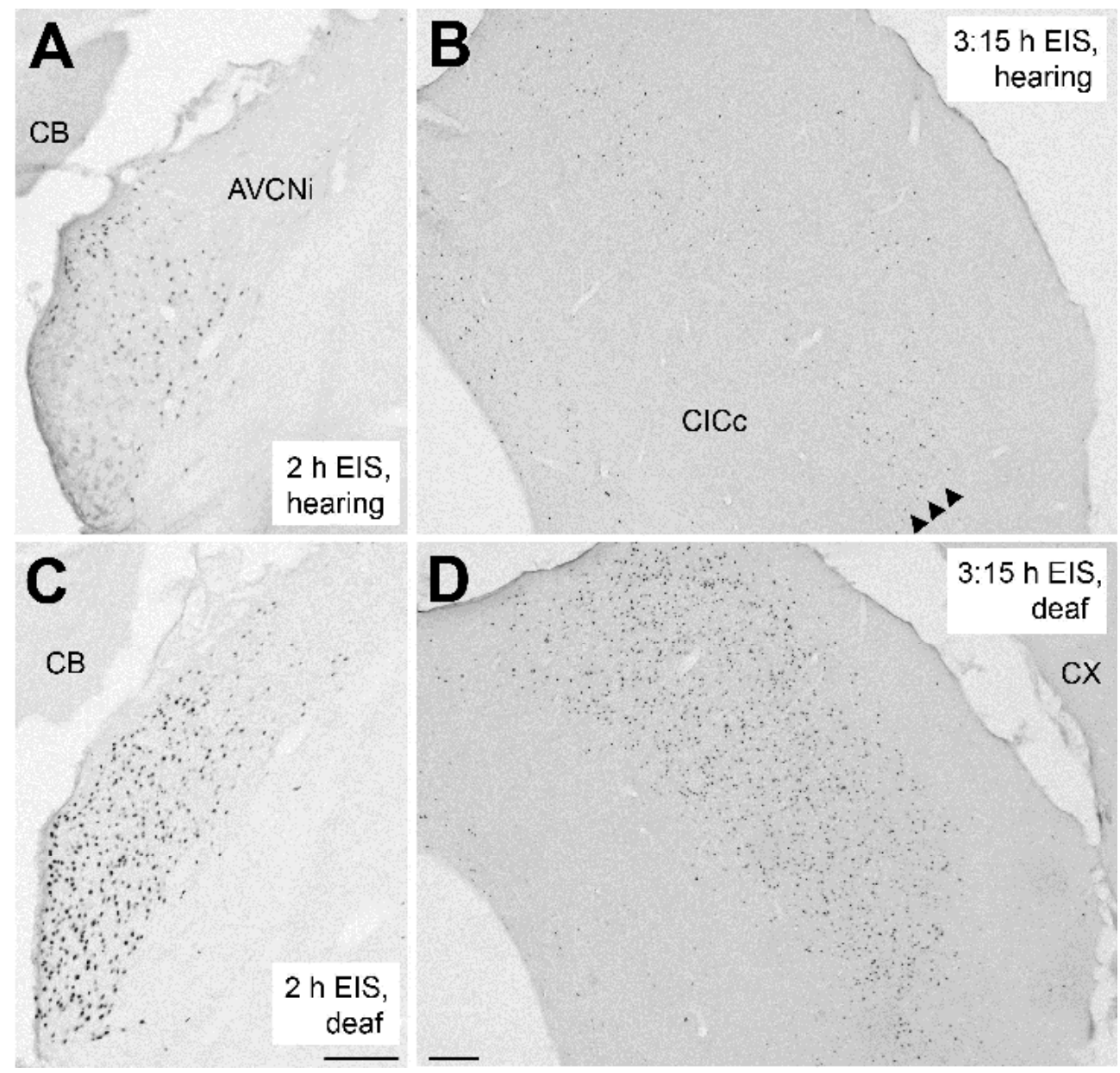

Fig. 12. Differences of c-Fos expression pattern in hearing vs. deafened rats. (A) Tonotopic cFos expression (black dots) in AVCNi of a hearing rat after $2 \mathrm{~h}$ of EIS. (B) Tonotopic band (arrowheads) of c-Fos positive nuclei (black dots) in CICc of a hearing rat after 3:15 h of EIS. (C) Non-tonotopic c-Fos expression (black dots) in AVCNi of a deaf rat after $2 \mathrm{~h}$ of EIS. (D) Strong and extended c-Fos expression (black dots) in the dorsolateral part of the CICc of a deaf rat after 3:15 h of EIS. i: ipsilateral; c: contralateral; CB: cerebellum; CX: Neocortex. Scale bars: $0.2 \mathrm{~mm}$.

Second, the composition of c-Fos expressing subpopulation changed with the preceding hearing experience (Fig. 13). 

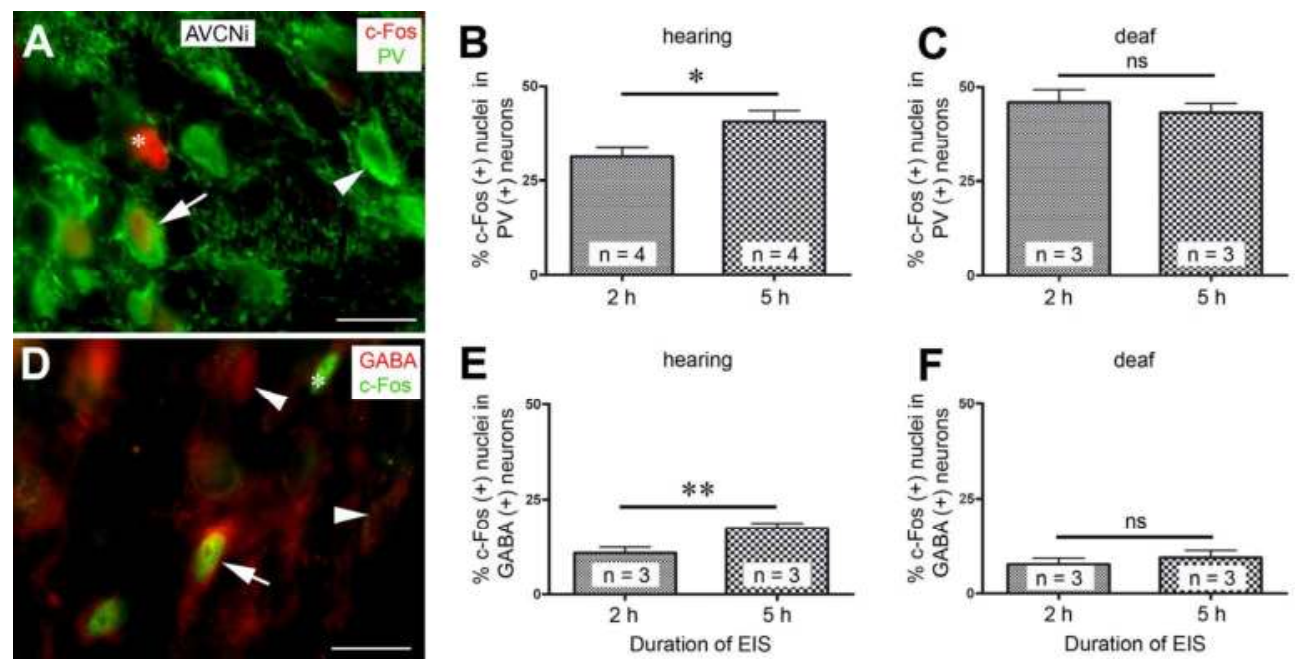

Fig. 13. Composition of c-Fos expressing subpopulations changed depending on preceding hearing experience and stimulation time. (A) Co-localization (arrow) of c-Fos positive nuclei (red, asterisk) and parvalbumin (PV)-positive neurons (green, arrowhead) in the AVCNi after EIS. (B, C) Statistic evaluation of co-localization of c-Fos positive nuclei and PVpositive neurons resulted only for hearing rats $(B, p=0.018)$ but not for deaf rats $(C)$ in a significant increase of double-labeling from 2 to $5 \mathrm{~h}$ of stimulation. (D) Following EIS, c-Fos expression (green, asterisk) was also co-localized (arrow) with GABAergic somata (red, arrowhead) in marginal zones of AVCNi. Scale bar: $20 \mu \mathrm{m}$. (E, F) The statistic evaluation of co-localization of c-Fos positive nuclei and GABA-positive neurons resulted only for hearing rats $(E, p=0.006)$ and not for deaf rats $(F)$ in a significant increase of double-labeling from 2 to $5 \mathrm{~h}$ of EIS. i: ipsilateral; ns: non-significant.

\section{Conclusions and outlook}

The brain is responsive to changes of activity in sensory nerves by forming memory traces on all its levels, from forebrain to hindbrain, and from molecules to neuronal networks. A successful therapy for patients with dysfunctional ears requires a CI that plays patterns of electrical activity corresponding to patterns of sound to the auditory nerve, and a moldable brain responding to this pattern. This response must include the initiation of molecular and synaptic reorganization to make optimal use of sensory-evoked activity, specifically to identify and categorize temporal patterns in spoken language (Munro, 2008; Anderson et al., 2010; Skoe \& Kraus 2010). Obviously, then, it is fundamentally important to run the $\mathrm{CI}$ in a way that fully exploits the neuroplastic potential of the central auditory system. It is therefore essential to detect short and long term molecular and cellular changes in the central nervous system in response to EIS equivalent to CI stimulation to understand which stimulation parameters are more important than others to elicit a full and focused plasticity response.

As we showed, specific conditions of afferent activity prompt specific populations of neurons in specific regions of the auditory brainstem to prepare for a molecular, structural, 
and functional remodeling within hours. Laterality, frequency, duration, and intensity of the stimulus each affect different neuronal populations across different regions. Coding of laterality takes place below the midbrain, but appears to be integrated in network activity from the inferior colliculus upwards. Each major brainstem region involved in the analysis of auditory stimuli respond to specific stimulation parameters by a unique dynamic pattern of c-Fos expression. With our studies we have made a first and perhaps a second and third step to understand central auditory plasticity, and there is reason to consider much of our data obtained from a mammalian brain transferable to man. However, our studies are not yet comprehensive in the sense that they already provide binding recommendations to $\mathrm{CI}$ programmers or users. Instead, it provides data showing for the first time that the parameters of running a CI bear a very real potential for neuroplastic remodeling of the central auditory system, and that the brain is certain to show a wealth of molecular and cellular responses to CI stimulation.

More stimulation parameters must be tested and more molecular markers monitored in order to delineate robust relationships between modes of stimulation, molecular processes, cellular growth, network remodeling, and the efficiency of signal processing. The knowledge so obtained will set the stage for the development of CIs in the future.

\section{Acknowledgements}

It is a pleasure to express our gratefulness to many co-workers for help: Heika Hildebrandt, Ann-Kathrin Rauch, Peter Bischoff, Till Jakob, Ulrike Doering, Michaela Fredrich, Eike Michalk, Peter Pedersen, Jürgen John, Alexander Huber, Ralf Birkenhäger, and Sigrid Weis. Moreover, thanks go to Cochlear Deutschland $\mathrm{GmbH}$ for kindly providing hard- and software used for EIS, and to Roland Laszig for continuous support.

\section{List of abbreviations}

2DG, 2-desoxy-D-glucose

$\mathrm{ABR}$, auditory brainstem response

AP-1, activator protein-1

Arc, activity-regulated cytoskeleton-associated protein

ATF-2, activating transcription factor-2

AVCN, anteroventral cochlear nucleus

AVCNc, AVCN contralateral to stimulation

AVCNi, AVCN ipsilateral to stimulation

B50, synonym for GAP-43

BDNF, brain derived neurotrophic factor

bFGF, basic fibroblast growth factor, same as FGF2

c, contralateral

CaMKIV, $\mathrm{Ca}^{2+} /$ calmodulin-dependent protein kinases IV

cAMP, cyclic adenosine monophosphate

$\mathrm{CB}$, cerebellum

c-fos, Finkel-Biskin-Jinkins murine osteosarcoma viral oncogene

c-Fos, protein encoded by proto-oncogene $c$-fos

CI, cochlear implant 
CIC, central nucleus of the inferior colliculus

$\mathrm{CICc}, \mathrm{CIC}$ contralateral to stimulation

c-jun, avian sarcoma virus 17, 'Jun' being derived from Japanese 'ju-nana' for '17'

c-Jun, protein encoded by immediate-early gene $c$-jun

Co, control

CRE, cAMP response element

CREB, cAMP response element-binding protein

cRNA, coding ribonucleic acid

CX, neocortex

d, dorsal

$\mathrm{DAB}, 3,3^{\prime}$-diaminobenzidine tetrahydrochloride

$\mathrm{dB}$, decibel

DCN, dorsal cochlear nucleus

DCNi, DCN ipsilateral to stimulation

DIG, digoxigenin

DMSO, dimethyl sulphoxide

DNA, deoxyribonucleic acid

EABR, electrical auditory brainstem response

Egr-1, early growth response protein-1

EIS, electrical intracochlear stimulation

$\mathrm{EP}$, evoked potential

EphA4, ephedrine A4

ERK, extracellular signal regulated kinase, mitogen-activated protein (MAP) kinases, variants 1 and 2

F1, synonym for GAP-43

FAP, activator protein-1 (AP-1)-like sequence

GABA, gamma amino butyric acid

GAP-43, growth-associated protein- 43

Glu, glutamate

Gly, glycine

$\mathrm{HuD}$, member of human $\mathrm{Hu}$ proteins identified as target antigens in autoimmune paraneoplastic encephalomyelitis-sensory neuronopathy, RNA-binding and stabilizing protein.

$\mathrm{Hz}$, Hertz

i, ipsilateral

i.p., intraperitoneal

IC, inferior colliculus

IHC, immunhistochemistry

ISH, in situ hybridization

Krox-24, synonym for Egr-1

1, lateral

LOC, lateral olivocochlear

LSO, lateral superior olivary complex

LSOc, LSO contralateral to stimulation

LSOi, LSO ipsilateral to stimulation

$\mathrm{m}$, medial

MAPK, mitogen-activated protein kinase

MGB, medial geniculate body 
MGBc, MGB contralateral to stimulation

mRNA, messenger ribonucleic acid

$\mathrm{n} 7$, facial nerve

NGF, nerve growth factor

NGFI-A, nerve growth factor-induced protein 1, synonym for Egr-1

NMDA, N-methyl-D-aspartic acid

ns, non-significant

$\mathrm{P}$, postnatal day

p38, protein phosphorylating specific MAPKs

P-57, synonym for GAP-43

p75(NTR), p75 neurotrophin receptor

p-ATF-2, phosphorylated activating transcription factor-2

PBS, phosphate-buffered saline

PCR, polymerase chain reaction

p-CREB, phosphorylated cAMP response element binding protein

p-ERK, phosphorylated ERK

pp46, synonym for GAP-43

$\mathrm{PV}$, parvalbumin

SIE, sis inducible element associated to retroviral DNA sequences (v-sis) originally isolated from simian sarcoma virus

SPL, sound pressure level

SRE, serum response element

SSC, standard saline citrate

Syngr-1, Synaptogyrin-1

Tis8, synonym for Egr-1

TrkA, neurotrophic tyrosine kinase receptor type 1

TrkB, neurotrophic tyrosine kinase receptor type 2

tRNA, transfer ribonucleic acid

$\mathrm{VCN}$, ventral cochlear nucleus

VCNc, VCN contralateral to stimulation

VNTB, ventral nucleus of the trapezoid body

Zenk, synonym for Egr-1

Zif268, synonym for Egr-1

\section{References}

Ackermann, J.; Ashton, G.; Lyons, S.; James, D.; Hornung, J.P.; Jones, N. \& Breitwieser W. (2011). Loss of ATF2 function leads to cranial motoneuron degeneration during embryonic mouse development. PLoS One, Vol.6, No.4, e19090.

Adams, J.C. (1995). Sound stimulation induces Fos-related antigens in cells with common morphological properties throughout the auditory brainstem. Journal of Comparative Neurology, Vol. 361, No. 4, pp. 645-668.

Aigner, L.; Arber, S.; Kapfhammer, J.P.; Laux, T.; Schneider, C.; Botteri, F.; Brenner, H.R. \& Caroni, P. (1995). Overexpression of the neural growth-associated protein GAP-43 induces nerve sprouting in the adult nervous system of transgenic mice. Cell, Vol. 83, No. 2, pp. 269-278. 
Anderson, S.; Skoe, E.; Chandrasekaran, B. \& Kraus, N. (2010). Neural timing is linked to speech perception in noise. Journal of Neuroscience Vol. 30, No. 14, pp. 4922-4926.

Benowitz, L.I. \& Perrone-Bizzozero, N.I. (1991). The expression of GAP-43 in relation to neuronal growth and plasticity: When, where, how, and why? Progress in Brain Research, Vol. 89, pp. 69-87.

Benowitz, L.I. \& Routtenberg, A. (1997). GAP-43: an intrinsic determinant of neuronal development and plasticity. Trends in Neuroscience, Vol.20, No. 2, pp. 84-91.

Benowitz, L.I.; Apostolides, P.J.; Perrone-Bizzozero, N.; Finklestein, S.P. \& Zwiers, H. (1988). Anatomical distribution of the growth-associated protein GAP-43/B-50 in the adult rat brain. Journal of Neuroscience, Vol. 8, No. 1, pp. 339-352.

Black, J.E.; Isaacs, K.R.; Anderson, B.J.; Alcantara, A.A. \& Greenough, W.T. (1990). Learning causes synaptogenesis, whereas motor activity causes angiogenesis, in cerebellar cortex of adult rats. Proceedings of the National Academy of Science USA, Vol. 87, No. 14, pp. 5568-5572.

Brami-Cherrier, K.; Roze, E.; Girault, J.A.; Betuing, S. \& Caboche, J. (2009). Role of the ERK/MSK1 signalling pathway in chromatin remodelling and brain responses to drugs of abuse. Journal of Neurochemistry, Vol. 108, No. 6, pp. 1323-1335.

Brown, M.C. \& Liu, T.S. (1995). Fos-like immunoreactivity in central auditory neurons of the mouse. Journal of Comparative Neurology, Vol. 357, No. 1, pp. 85-97.

Campeau, S.; Dolan, D.; Akil, H. \& Watson, S.J. (2002). c-fos mRNA induction in acute and chronic audiogenic stress: possible role of the orbitofrontal cortex in habituation. Stress, Vol.5, No. 2, pp. 121-130.

Campeau, S.; Watson, S.J. (1997). Neuroendocrine and behavioral responses and brain pattern of cfos induction associated with audiogenic stress. Journal of Neuroendocrinology, Vol.9, No. 8, pp. 577-588.

Carretta, D.; Hervé-Minvielle, A.; Bajo, V.M.; Villa, A.E. \& Rouiller, E.M. (1999). c-Fos expression in the auditory pathways related to the significance of acoustic signals in rats performing a sensory-motor task. Brain Research, Vol. 841, No. 1-2, pp. 170-183.

Chung, S.; Jiang, L.; Cheng, S. \& Furneaux, H. (1996). Purification and properties of HuD, a neuronal RNA-binding protein. Journal of Biological Chemistry, Vol. 271, No. 19, pp. 11518-11524.

Clarkson, C.; Juíz, J.M. \& Merchán, M.A. (2010). Transient down-regulation of sound-induced cFos protein expression in the inferior colliculus after ablation of the auditory cortex. Frontiers in Neuroanatomy, Vol. 4, Article 141.

Curran, T.; Miller, A.D.; Zokas, L. \& Verma, I.M. (1984). Viral and cellular fos proteins: a comparative analysis. Cell, Vol.36, No. 2, pp. 259-268.

De Graan, P.N.; Van Hooff, C.O.; Tilly, B.C.; Oestreicher, A.B.; Schotman, P. \& Gispen, W.H. (1985). Phosphoprotein B-50 in nerve growth cones from fetal rat brain. Neuroscience Letters, Vol. 61, No. 3, pp. 235-241.

De, S.; Shuler, C.F. \& Turman, J.E. Jr. (2003). The ontogeny of Krox-20 expression in brainstem and cerebellar neurons. Journal of Chemical Neuroanatomy, Vol. 25, No. 3, pp. 213-226.

Diolaiti, D.; Bernardoni, R.; Trazzi, S.; Papa, A.; Porro, A.; Bono, F.; Herbert, J.M.; Perini, G. \& Della Valle, G. (2007). Functional cooperation between TrkA and $p 75$ (NTR) accelerates neuronal differentiation by increased transcription of GAP-43 and p21(CIP/WAF) genes via ERK1/2 and AP-1 activities. Experimental Cell Research, Vol. 313, No. 14, pp. 2980-2992. 
Edling, Y.; Ingelman-Sundberg, M. \& Simi, A. (2007). Glutamate activates c-fos in glial cells via a novel mechanism involving the glutamate receptor subtype $m G l u 5$ and the transcriptional repressor DREAM. Glia, Vol. 55, No. 3, pp. 328-340.

Edsjö, A.; Hallberg, B.; Fagerström, S.; Larsson, C.; Axelson, H. \& Påhlman, S. (2001). Differences in early and late responses between neurotrophin-stimulated trkA- and trkCtransfected SH-SY5Y neuroblastoma cells. Cell Growth Differentiation, Vol. 12, No. 1, pp. 39-50.

Ehret, G. \& Fischer, R. (1991). Neuronal activity and tonotopy in the auditory system visualized by c-fos gene expression. Brain Research, Vol. 567, No. 2, pp. 350-354.

Fichtel, I. \& Ehret, G. (1999). Perception and recognition discriminated in the mouse auditory cortex by c-Fos labeling. Neuroreport, Vol. 10, No. 11, pp. 2341-2345.

Friauf, E. (1995). C-fos immunocytochemical evidence for acoustic pathway mapping in rats. Behavioral Brain Research, Vol. 66, No. 1-2, pp. 217-224.

Fujii, K.; Saika, T.; Yamamoto, K.; Doi, K. \& Kubo, T. (1997). Electrically evoked auditory brainstem response and Fos-immunoreactivity in kanamycin-deafened rats. Advances in Otorhinolaryngology, Vol. 52, pp. 27-29.

Gao, Y.J. \& Ji, R.R. (2009). c-Fos and pERK, which is a better marker for neuronal activation and central sensitization after noxious stimulation and tissue injury? Open Pain Journal Vol. 2, pp. 11-17.

Geissler, D.B. \& Ehret, G. (2004). Auditory perception vs. recognition: representation of complex communication sounds in the mouse auditory cortical fields. European Journal of Neuroscience, Vol. 19, No. 4, pp. 1027-40.

Gil-Loyzaga, P.; Carricondo, F.; Bartolomé, M.V.; Iglesias, M.C.; Rodríguez, F. \& Poch-Broto, J. (2010). Cellular and molecular bases of neuroplasticity: brainstem effects after cochlear damage. Acta Otolaryngologica, Vol. 130, No. 3, pp. 318-325.

Ginty, D.D.; Bonni, A. \& Greenberg, M.E. (1994). Nerve growth factor activates a Ras-dependent protein kinase that stimulates c-fos transcription via phosphorylation of CREB. Cell, Vol. 77, No. 5, pp. 713-725.

Gispen, W.H.; Nielander, H.B.; De Graan, P.N.E.; Oestreicher, A.B.; Schrama, L.H. \& Schotman P. (1991). Role of the growth-associated protein B-50/GAP-43 in neuronal plasticity. Molecular Neurobiology, Vol. 5, No. 2-3, pp. 61-85.

Harris, J.A.; Hardie, N.A.; Bermingham-McDonogh, O. \& Rubel. E.W. (2005). Gene expression differences over a critical period of afferent-dependent neuron survival in the mouse auditory brainstem. Journal of Comparative Neurology, Vol. 493, No. 3, pp. 460-474.

Harris, J.A.; Iguchi, F.; Seidl, A.H.; Lurie, D.I. \& Rubel, E.W. (2008). Afferent deprivation elicits a transcriptional response associated with neuronal survival after a critical period in the mouse cochlear nucleus. Journal of Neuroscience, Vol. 28, No. 43, pp. 10990-11002.

Herdegen, T. \& Leah, J.D. (1998). Inducible and constitutive transcription factors in the mammalian nervous system: Control of gene expression by Jun, Fos and Krox, and CREB/ATF proteins. Brain Research Reviews, Vol. 28, No. 3, pp. 370-490.

Hildebrandt, H.; Hoffmann, N.A. \& Illing, R.B. (2011). Synaptic reorganization in the adult rat's ventral cochlear nucleus following its total sensory deafferentation. PLoS One, Vol. 6, No. $8, \mathrm{e} 23686$.

Illing, R.B. \& Horváth, M. (1995). Re-emergence of GAP-43 in cochlear nucleus and superior olive following cochlear ablation in the rat. Neuroscience Letters, Vol. 194, No. 1-2, pp. 9-12. 
Illing, R.B. \& Michler S.A. (2001). Modulation of P-CREB and expression of c-Fos in cochlear nucleus and superior olive following electrical intracochlear stimulation. Neuroreport, Vol. 12, No. 4, pp. 875-878.

Illing, R.B. \& Reisch, A. (2006). Specific plasticity responses to unilaterally decreased or increased hearing intensity in the adult cochlear nucleus and beyond. Hearing Research, Vol. 216217, pp. 189-197.

Illing, R.B. (2001). Activity-dependent plasticity in the adult auditory brainstem. Audiology and Neurootology, Vol. 6, No. 6, pp. 319-345.

Illing, R.B.; Cao, Q.L.; Förster, C.R. \& Laszig, R. (1999). Auditory brainstem: development and plasticity of GAP-43 mRNA expression in the rat. Journal of Comparative Neurology, Vol. 412, No. 2, pp. 353-372.

Illing, R.B.; Horváth, M. \& Laszig, R. (1997). Plasticity of the auditory brainstem: effects of cochlear lesions on GAP-43 immunoreactivity in the rat. Journal of Comparative Neurology, Vol. 382, No. 1, pp. 116-138.

Illing, R.B.; Kraus, K.S. \& Meidinger, M.A. (2005). Reconnecting neuronal networks in the auditory brainstem following unilateral deafening. Hearing Research, Vol. 206, No. 1-2, pp. 185-199.

Illing, R.B.; Michler, S.A.; Kraus, K.S. \& Laszig, R. (2002). Transcription factor modulation and expression in the rat auditory brainstem following electrical intracochlear stimulation. Experimental Neurology, Vol. 175, No. 1, pp. 226-244.

Illing, R.B.; Rosskothen-Kuhl, N.; Fredrich, M.; Hildebrandt, H. \& Zeber, A.C. (2010). Imaging the plasticity of the central auditory system on the cellular and molecular level. Audiological Medicine, Vol. 8, No. 2, pp. 63-76.

Irving, S.; Moore, D.R.; Liberman, M.C. \& Sumner CJ. (2011). Olivocochlear efferent control in sound localization and experience-dependent learning. Journal of Neuroscience, Vol. 31, No. 7, pp. 2493-2501.

Ishida, Y.; Nakahara, D.; Hashiguchi, H.; Nakamura, M.; Ebihara, K.; Takeda, R.; Nishimori, T. \& Niki H. (2002). Fos expression in GABAergic cells and cells immunopositive for NMDA receptors in the inferior and superior colliculi following audiogenic seizures in rats. Synapse, Vol. 46, No. 2, pp. 100-107.

Jakob, T. \& Illing, R.B. (2008). Laterality, intensity, and frequency of electrical intracochlear stimulation are differentially mapped into specific patterns of gene expression in the rat auditory brainstem. Audiological Medicine, Vol. 6, No. 3, pp. 215-227.

Jero, J.; Coling, D.E. \& Lalwani, A.K. (2001). The use of Preyer's reflex in evaluation of hearing in mice. Acta Otolaryngologica, Vol.121, No. 5, pp. 585-589.

Kai, N. \& Niki, H. (2002). Altered tone-induced Fos expression in the mouse inferior colliculus after early exposure to intense noise. Neuroscience Research, Vol. 44, No. 3, pp. 305-313.

Keilmann, A \& Herdegen, T. (1995). Expression of the c-fos transcription factor in the rat auditory pathway following postnatal auditory deprivation. European Archive of Otorhinolaryngology, Vol. 252, No. 5, pp. 287-291.

Keilmann, A \& Herdegen, T. (1997). The c-Fos transcription factor in the auditory pathway of the juvenile rat: effects of acoustic deprivation and repetitive stimulation. Brain Research, Vol. 753, No. 2, pp. 291-298.

Kinney, H.C.; Rava, L.A. \& Benowitz, L.I. (1993). Anatomic distribution of the growth-associated protein GAP-43 in the developing human brainstem. Journal of Neuropathology and Experimental Neurology, Vol. 52, No. 1, pp. 39-54. 
Kleim, J.A.; Lussnig, E.; Schwarz, E.R.; Comery, T.A. \& Greenough, W.T. (1996). Synaptogenesis and Fos expression in the motor cortex of the adult rat after motor skill learning. Journal of Neuroscience, Vol. 16, No. 14, pp. 4529-4535.

Koponen, E.; Lakso, M. \& Castrén, E. (2004). Overexpression of the full-length neurotrophin receptor trkB regulates the expression of plasticity-related genes in mouse brain. Molecular Brain Research, Vol. 130, No. 1-2, pp. 81-94.

Kraus, K.S. \& Illing, R.B. (2004). Superior olivary contributions to auditory system plasticity: medial but not lateral olivocochlear neurons are the source of cochleotomy-induced GAP-43 expression in the ventral cochlear nucleus. Journal of Comparative Neurology, Vol. 475, No. 3, pp. 374-390.

Lu, H.P.; Chen, S.T. \& Poon, P.W. (2009). Nuclear size of c-Fos expression at the auditory brainstem is related to the time-varying nature of the acoustic stimuli. Neuroscience Letters, Vol. 451, No. 2, pp. 139-143.

Luo, L.; Ryan, A.F. \& Saint Marie, R.L. (1999). Cochlear ablation alters acoustically induced c-fos $m R N A$ expression in the adult rat auditory brainstem. Journal of Comparative Neurology, Vol. 404, No. 2, pp. 271-283.

Mahalik, T.J.; Carrier, A.; Owens, G.P. \& Clayton, G. (1992). The expression of GAP43 mRNA during the late embryonic and early postnatal development of the CNS of the rat: An in situ hybridization study. Developmental Brain Research, Vol. 67, No. 1, pp. 75-83.

Matsuda, K.; Ueda, Y.; Doi, T.; Tono, T.; Haruta, A.; Toyama, K. \& Komune, S. (1999). Increase in glutamate-aspartate transporter (GLAST) mRNA during kanamycin-induced cochlear insult in rats. Hearing Research, Vol. 133, No. 1-2, pp. 10-16.

McNamara, J.O.; Bonhaus, D.W. \& Shin, C. (1993). The kindling model of epilepsy. In: Epilepsy: models, mechanisms, and concepts , P.A. Schwartzkroin, (Ed.), 27-47. Cambridge, UK: Cambridge UP.

Meidinger, M.A.; Hildebrandt-Schoenfeld, H. \& Illing, R.B. (2006). Cochlear damage induces GAP-43 expression in cholinergic synapses of the rat cochlear nucleus in the adult rat: A light and electron microscopical study. European Journal of Neuroscience, Vol. 23, No. 12, pp. 3187-3199.

Meiri, K.F.; Saffell, J.L.; Walsh, F.S. \& Doherty, P. (1998). Neurite outgrowth stimulated by neural cell adhesion molecules requires growth-associated protein-43 (GAP-43) function and is associated with GAP-43 phosphorylation in growth cones. Journal of Neuroscience, Vol. 18, No. 24, pp. 10429-10437.

Metz, G.A. \& Schwab, M.E. (2004). Behavioral characterization in a comprehensive mouse test battery reveals motor and sensory impairments in growth-associated protein-43 null mutant mice. Neuroscience, Vol. 129, No. 3, pp. 563-574.

Michler, S.A. \& Illing, R.B. (2003). Molecular plasticity in the rat auditory brainstem: Modulation of expression and distribution of phosphoserine, phospho-CREB and TrkB after noise trauma. Audiology and Neurootology, Vol. 8, No. 4, pp. 190-206.

Miko, I.J.; Nakamura, P.A.; Henkemeyer, M. \& Cramer, K.S. (2007). Auditory brainstem neural activation patterns are altered in EphA4- and ephrin-B2-deficient mice. Journal of Comparative Neurology, Vol. 505, No. 6, pp. 669-681.

Mobarak, C.D.; Anderson, K.D.; Morin, M.; Beckel-Mitchener, A.; Rogers, S.L.; Furneaux, H.; King, P. \& Perrone-Bizzozero, N.I. (2000). The RNA-binding protein HuD is required for GAP-43 mRNA stability, GAP-43 gene expression, and PKC-dependent neurite outgrowth in PC12 cells. Molecular Biology of the Cell, Vol. 11, No. 9, pp. 3191-3203. 
Müller, R., Bravo, R., Burckhardt, J. \& Curran, T. (1984). Induction of c-fos gene and protein by growth factors precedes activation of c-myc. Nature, Vol. 312, No. 5996, pp. 716-720.

Munro, K.J. (2008). Reorganization of the adult auditory system: perceptual and physiological evidence from monaural fitting of hearing aids. Trends in Amplification, Vol. 12, No. 3, pp. 254-271.

Nagase, S.; Miller, J.M.; Dupont, J.; Lim, H.H.; Sato, K. \& Altschuler, R.A. (2000). Changes in cochlear electrical stimulation induced Fos expression in the rat inferior colliculus following deafness. Hearing Research, Vol. 147, No. 1-2, pp. 242-250.

Nagase, S.; Mukaida, M.; Miller, J.M. \& Altschuler, R.A. (2003). Neonatal deafening causes changes in Fos protein induced by cochlear electrical stimulation. Journal of Neurocytology, Vol. 32, No. 4, pp. 353-361.

Nakamura, M.; Rosahl, S.K.; Alkahlout, E.; Gharabaghi, A.; Walter, G.F. \& Samii, M. (2003). C-Fos immunoreactivity mapping of the auditory system after electrical stimulation of the cochlear nerve in rats. Hearing Research, Vol. 184, No. 1-2, pp. 75-81.

Nakamura, M.; Rosahl, S.K.; Alkahlout, E.; Walter, G.F. \& Samii, M.M. (2005). Electrical stimulation of the cochlear nerve in rats: analysis of c-Fos expression in auditory brainstem nuclei. Brain Research, Vol. 1031, No. 1, pp. 39-55.

Nedivi, E.; Basi, G.S.; Akey, I.V. \& Skene, J.H. (1992). A neural-specific GAP-43 core promoter located between unusual DNA elements that interact to regulate its activity. Journal of Neuroscience, Vol. 12, No. 3, pp. 691-704.

Oh, S.H.; Kim, C.S. \& Song, J.J. (2007). Gene expression and plasticity in the rat auditory cortex after bilateral cochlear ablation. Acta Otolaryngologica, Vol. 127, No. 4, pp. 341-350.

Osako, S.; Tokimoto, T. \& Matsuura, S. (1979). Effects of kanamycin on the auditory evoked responses during postnatal development of the hearing of the rat. Acta Otolaryngologica, Vol. 88, No. 5-6, 359-368.

Ota, K.T.; Monsey, M.S.; Wu, M.S.; Young, G.J. \& Schafe, G.E. (2010). Synaptic plasticity and $N O-c G M P-P K G$ signaling coordinately regulate ERK-driven gene expression in the lateral amygdala and in the auditory thalamus following Pavlovian fear conditioning. Learning and Memory, Vol. 17, No. 4, pp. 221-235.

Peña, M.; Maki, A.; Kovacić, D.; Dehaene-Lambertz, G.; Koizumi, H.; Bouquet, F. \& Mehler, J. (2003). Sounds and silence: an optical topography study of language recognition at birth. Proceedings of the National Academy of Science USA, Vol. 100, No. 20, pp. 1170211705.

Pierson, M. \& Snyder-Keller, A. (1994). Development of frequency-selective domains in inferior colliculus of normal and neonatally noise-exposed rats. Brain Research, Vol. 636, No. 1, pp. 55-67.

Pollin, B. \& Albe-Fessard, D. (1979). Organization of somatic thalamus in monkeys with and without section of dorsal spinal tracts. Brain Research, Vol. 173, No. 3, pp. 431-449.

Racaniello, M.; Cardinale, A.; Mollinari, C.; D'Antuono, M.; De Chiara, G.; Tancredi, V. \& Merlo D. (2010). Phosphorylation changes of CaMKII, ERK1/2, PKB/Akt kinases and CREB activation during early long-term potentiation at Schaffer collateral-CA1 mouse hippocampal synapses. Neurochemical Research, Vol. 35, No. 2, pp. 239-246.

Reisch, A.; Illing, R.B. \& Laszig, R. (2007). Immediate early gene expression invoked by electrical intracochlear stimulation in some but not all types of neurons in the rat auditory brainstem. Experimental Neurology, Vol. 208, No. 2, pp. 193-206.

Rekart, J.L.; Meiri, K. \& Routtenberg, A. (2005). Hippocampal-dependent memory is impaired in heterozygous GAP-43 knockout mice. Hippocampus, Vol. 15, No. 1, pp. 1-7. 
Robinson, G.A. (1996). Changes in the expression of transcription factors ATF-2 and Fra-2 after axotomy and during regeneration in rat retinal ganglion cells. Molecular Brain Research, Vol. 41, No. 1-2, pp. 57-64.

Rosskothen, N.; Hirschmüller-Ohmes, I. \& Illing, R.B. (2008). AP-1 activity rises by stimulation-dependent c-Fos expression in auditory neurons. Neuroreport, Vol. 19, pp. 1091-1093.

Rosskothen-Kuhl, N. \& Illing R.B. (2010). Nonlinear development of the populations of neurons expressing c-Fos under sustained electrical intracochlear stimulation in the rat auditory brainstem. Brain Research, Vol. 1347, No. 11, pp. 33-41.

Rosskothen-Kuhl, N. \& Illing R.B. (2012) The impact of hearing experience on signal integration in the auditory brainstem: A c-Fos study of the rat. Brain Research, Vol. 1435, No. 1, pp. 40-55.

Rouiller, E.M.; Wan, X.S.; Moret, V. \& Liang, F. (1992). Mapping of c-fos expression elicited by pure tones stimulation in the auditory pathways of the rat, with emphasis on the cochlear nucleus. Neuroscience Letters, Vol. 144, No. 1-2, pp. 19-24.

Ruan, Q.; Wang, D.; Gao, H.; Liu, A.; Da, C.; Yin, S. \& Chi, F. (2007). The effects of different auditory activity on the expression of phosphorylated c-Jun in the auditory system. Acta Otolaryngologica, Vol. 127, No. 6, pp. 594-604.

Saint Marie, R.L.; Luo, L. \& Ryan, A.F. (1999A). Spatial representation of frequency in the rat dorsal nucleus of the lateral lemniscus as revealed by acoustically induced c-fos mRNA expression. Hearing Research, Vol. 128, No. 1-2, pp. 70-74.

Saint Marie, R.L.; Luo, L. \& Ryan A.F. (1999B). Effects of stimulus frequency and intensity on cfos mRNA expression in the adult rat auditory brainstem. Journal of Comparative Neurology, Vol. 404, No. 2, pp. 258-270.

Saito, H.; Miller, J.M. \& Altschuler, R.A. (2000). Cochleotopic fos immunoreactivity in cochlea and cochlear nuclei evoked by bipolar cochlear electrical stimulation. Hearing Research, Vol. 145, No. 1-2, pp. 37-51.

Saito, H.; Miller, J.M.; Pfingst, B.E. \& Altschuler, R.A. (1999). Fos-like immunoreactivity in the auditory brainstem evoked by bipolar intracochlear electrical stimulation: effects of current level and pulse duration. Neuroscience, Vol. 91, No. 1, pp. 139-161.

Sakamoto, K.M.; Bardeleben, C.; Yates, K.E.; Raines, M.A.; Golde, D.W. \& Gasson, J.C. (1991). 5' upstream sequence and genomic structure of the human primary response gene, EGR-1/TIS8. Oncogene, Vol. 6, No. 5, pp. 867-871.

Sato, K.; Houtani, T.; Ueyama, T.; Ikeda, M.; Yamashita, T.; Kumazawa, T. \& Sugimoto T. (1993). Identification of rat brainstem sites with neuronal Fos protein induced by acoustic stimulation with pure tones. Acta Otolaryngologica, Supplement, Vol. 500, pp. 18-22.

Schaechter, J.D. \& Benowitz, L.I. (1993). Activation of protein kinase C by arachidonic acid selectively enhances the phosphorylation of GAP-43 in nerve terminal membranes. Journal of Neuroscience, Vol. 13, No. 10, pp. 4361-4371.

Scheich, H. \& Zuschratter, W. (1995). Mapping of stimulus features and meaning in gerbil auditory cortex with 2-deoxyglucose and c-Fos antibodies. Behavioral Brain Research, Vol. 66, No. 1-2, pp. 195-205.

Schwachtgen, J.L.; Campbell, C.J. \& Braddock M. (2000). Full promoter sequence of human early growth response factor-1 (Egr-1): Demonstration of a fifth functional serum response element. DNA Sequencing, Vol. 10, No. 6, pp. 429-432.

Sharp, F.R.; Sagar, S.M. \& Swanson, R.A. (1993). Metabolic mapping with cellular resolution: cfos vs. 2-deoxyglucose. Critical Reviews in Neurobiology, Vol. 7, No. 3-4, pp. 205-228. 
Shea, T.B.; Perrone-Bizzozero, N.I.; Beermann, M.L. \& Benowitz, L.I. (1991). Phospholipidmediated delivery of anti-GAP-43 antibodies into neuroblastoma cells prevents neuritogenesis. Journal of Neuroscience, Vol. 11, No. 6, pp. 1685-1690.

Sheng, M. \& Greenberg, M.E. (1990). The regulation and function of c-fos and other immediate early genes in the nervous system. Neuron, Vol. 4, No. 4, pp. 477-485.

Shibata, F.; Baird, A. \& Florkiewicz, R.Z. (1991). Functional characterization of the human basic fibroblast growth factor gene promoter. Growth Factors, Vol. 4, No. 4, pp. 277-287.

Skene, J.H. \& Willard, M. (1981). Characteristics of growth-associated polypeptides in regenerating toad retinal ganglion cell axons. Journal of Neuroscience, Vol. 1, pp. 419-426.

Skene, J.H. (1989). Axonal growth-associated proteins. Annual Reviews of Neuroscience, Vol. 12, pp. 127-56.

Skoe, E \& Kraus, N. (2010). Hearing it again and again: on-line subcortical plasticity in humans. PLoS One, Vol. 5, No. 10, e13645.

Smith, C.L.; Afroz, R.; Bassell, G.J.; Furneaux, H.M.; Perrone-Bizzozero, N.I. \& Burry, R.W. (2004). GAP-43 mRNA in growth cones is associated with HuD and ribosomes. Journal of Neurobiology, Vol. 61, No. 2, pp. 222-235.

Strittmatter, S.M.; Fankhauser, C.; Huang, P.L.; Mashimo, H. \& Fishman, M.C. (1995). Neuronal pathfinding is abnormal in mice lacking the neuronal growth cone protein GAP43. Cell, Vol. 80, No. 3, pp. 445-452.

Sun, X.; Guo, Y.P. \& Shum, D.K.; Chan, Y.S. \& He J. (2009). Time course of cortically induced fos expression in auditory thalamus and midbrain after bilateral cochlear ablation. Neuroscience, Vol. 160, No. 1, pp. 186-197.

Suneja, S.K. \& Potashner, S.J. (2003). ERK and SAPK signaling in auditory brainstem neurons after unilateral cochlear ablation. Journal of Neuroscience Research, Vol. 73, No. 2, pp. 235-245.

Takagi, H.; Saito, H.; Nagase, S. \& Suzuki M. (2004). Distribution of Fos-like immunoreactivity in the auditory pathway evoked by bipolar electrical brainstem stimulation. Acta Otolaryngologica, Vol. 124, No. 8, pp. 907-913.

Tanabe, Y.; Hashimoto, M.; Sugioka, K.; Maruyama, M.; Fujii, Y.; Hagiwara, R.; Hara, T.; Hossain, S.M. \& Shido, O. (2004). Improvement of spatial cognition with dietary docosahexaenoic acid is associated with an increase in Fos expression in rat CA1 hippocampus. Clinical and Experimental Pharmacology and Physiology, Vol. 31, No. 10, pp. 700-703.

Tao, X.; Finkbeiner, S.; Arnold, D.B.; Shaywitz, A.J. \& Greenberg, M.E. (1998). Ca2+ influx regulates BDNF transcription by a CREB family transcription factor-dependent mechanism. Neuron, Vol. 20, No. 4, pp. 709-726.

van Dam, H. \& Castellazzi, M. (2001). Distinct roles of Jun:Fos and Jun:ATF dimers in oncogenesis. Oncogene, Vol. 20, No. 19, pp. 2453-2464.

Verhaagen, J.; Hermens, W.T.; Oestreicher, A.B.; Gispen, W.H.; Rabkin, S.D.; Pfaff, D.W. \& Kaplitt, M.G. (1994). Expression of the growth-associated protein B-50/GAP43 via a defective herpes-simplex virus vector results in profound morphological changes in nonneuronal cells. Molecular Brain Research, Vol. 26, No. 1-2, pp. 26-36.

Vischer, M.W.; Bajo-Lorenzana, V.; Zhang, J.; Häusler, R. \& Rouiller, E.M. (1995). Activity elicited in the auditory pathway of the rat by electrical stimulation of the cochlea. Journal of Otorhinolaryngology, Vol. 57, No. 6, pp. 305-309. 
Vischer, M.W.; Häusler, R. \& Rouiller E.M. (1994). Distribution of Fos-like immunoreactivity in the auditory pathway of the Sprague-Dawley rat elicited by cochlear electrical stimulation. Neuroscience Research, Vol. 19, No. 2, pp. 175-185.

Wall, P.D. \& Egger, M.D. (1971). Formation of new connexions in adult rat brains after partial deafferentation. Nature, Vol. 232, No. 5312, pp. 542-545.

Walton, J.P. (2010). Timing is everything: temporal processing deficits in the aged auditory brainstem. Hearing Research, Vol. 264, No. 1-2, pp. 63-69.

Wan, H.; Warburton, E.C.; Kuśmierek, P.; Aggleton, J.P.; Kowalska, D.M. \& Brown M.W. (2001). Fos imaging reveals differential neuronal activation of areas of rat temporal cortex by novel and familiar sounds. European Journal of Neuroscience, Vol. 14, No. 1, pp. 118-124.

Watanabe, Y.; Johnson, R.S.; Butler, L.S.; Binder, D.K.; Spiegelman, B.M.; Papaioannou, V.E. \& McNamara, J.O. (1996). Null mutation of c-fos impairs structural and functional plasticities in the kindling model of epilepsy. Journal of Neuroscience, Vol. 16, No. 12, pp. 3827-3836.

Weber, J.R. \& Skene J.H. (1998). The activity of a highly promiscuous AP-1 element can be confined to neurons by a tissue-selective repressive element. Journal of Neuroscience, Vol. 18, No. 18, pp. 5264-5274.

Widmer, F. \& Caroni, P. (1993). Phosphorylation-site mutagenesis of the growth-associated protein GAP-43 modulates its effects on cell spreading and morphology. Journal of Cell Biology, Vol. 120, No. 2, pp. 503-512.

Williams, S.; Evan, G. \& Hunt S.P. (1991). C-fos induction in the spinal cord after peripheral nerve lesion. European Journal of Neuroscience, Vol. 3, No. 9, pp. 887-894.

Wisdom, R. (1999). AP-1: One switch for many signals. Experimental Cell Research, Vol. 253, No. 1, pp. 180-185.

Woolf, C.J.; Reynolds, M.L.; Molander, C.; O’Brien, C.; Lindsay, R.M. \& Benowitz, L.I. (1990). The growth-associated protein GAP-43 appears in dorsal root ganglion cells and in the dorsal horn of the rat spinal cord following peripheral nerve injury. Neuroscience, Vol. 34, No. 2, pp. $465-478$.

Wu, J.L.; Chiu, T.W. \& Poon P.W. (2003). Differential changes in Fos-immunoreactivity at the auditory brainstem after chronic injections of salicylate in rats. Hearing Research, Vol. 176, No. 1-2, pp. 80-93.

Xu, B.; Gottschalk, W.; Chow, A.; Wilson, R.I.; Schnell, E.; Zang, K.; Wang, D.; Nicoll, R.A.; Lu, B. \& Reichardt L.F. (2000). The role of brain-derived neurotrophic factor receptors in the mature hippocampus: Modulation of long-term potentiation through a presynaptic mechanism involving TrkB. Journal of Neuroscience, Vol. 20, No. 18, pp. 6888-6897.

Yang, H.; Xia, Y.; Lu, S.Q.; Soong, T.W. \& Feng, Z.W. (2008). Basic fibroblast growth factorinduced neuronal differentiation of mouse bone marrow stromal cells requires FGFR-1, $M A P K / E R K$, and transcription factor AP-1. Journal of Biological Chemistry, Vol. 283, No. 9, pp. 5287-5295.

Yankner, B.A.; Benowitz, L.I.; Villa-Komaroff, L. \& Neve, R.L. (1990). Transfection of PC12 cells with the human GAP-43 gene: Effects on neurite outgrowth and regeneration. Molecular Brain Research, Vol. 7, No. 1, pp. 39-44.

Yuan, Z.; Gong, S.; Luo, J.; Zheng, Z.; Song, B.; Ma, S.; Guo, J.; Hu, C.; Thiel, G.; Vinson, C.; Hu, C.D.; Wang, Y. \& Li, M. (2009). Opposing roles for ATF2 and c-Fos in c-Junmediated neuronal apoptosis. Molecular and Cellular Biology, Vol. 29, No. 9, pp. 24312442. 
Zhang, J. \& Zhang, X. (2010). Electrical stimulation of the dorsal cochlear nucleus induces hearing in rats. Brain Research, Vol. 1311, pp. 37-50.

Zhang, J.S.; Haenggeli, C.A.; Tempini, A.; Vischer, M.W.; Moret, V. \& Rouiller, E.M. (1996). Electrically induced fos-like immunoreactivity in the auditory pathway of the rat: effects of survival time, duration, and intensity of stimulation. Brain Research Bulletin, Vol. 39, No. 2, pp. 75-82.

Zhang, J.S.; Vischer, M.W.; Moret, V.; Roulin, C. \& Rouiller, E.M. (1998). Antibody-dependent Fos-like immunoreactivity (FLI) in the auditory pathway of the rat in response to electric stimulation of the cochlea. Journal für Hirnforschung, Vol. 39, No. 1, pp. 21-35.

Zuschratter, W.; Gass, P.; Herdegen, T. \& Scheich, H. (1995). Comparison of frequency-specific c-Fos expression and fluoro-2-deoxyglucose uptake in auditory cortex of gerbils (Meriones unguiculatus). European Journal of Neuroscience, Vol. 7, No. 7, pp. 1614-1626. 


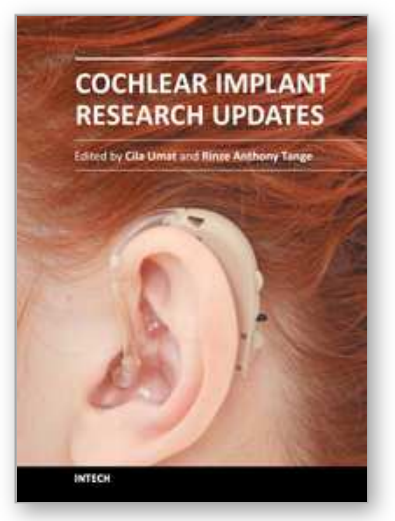

\author{
Cochlear Implant Research Updates \\ Edited by Dr. Cila Umat
}

ISBN 978-953-51-0582-4

Hard cover, 232 pages

Publisher InTech

Published online 27, April, 2012

Published in print edition April, 2012

For many years or decades, cochlear implants have been an exciting research area covering multiple disciplines which include surgery, engineering, audiology, speech language pathology, education and psychology, among others. Through these research studies, we have started to learn or have better understanding on various aspects of cochlear implant surgery and what follows after the surgery, the implant technology and other related aspects of cochlear implantation. Some are much better than the others but nevertheless, many are yet to be learnt. This book is intended to fill up some gaps in cochlear implant research studies. The compilation of the studies cover a fairly wide range of topics including surgical issues, some basic auditory research, and work to improve the speech or sound processing strategies, some ethical issues in language development and cochlear implantation in cases with auditory neuropathy spectrum disorder. The book is meant for postgraduate students, researchers and clinicians in the field to get some updates in their respective areas.

\title{
How to reference
}

In order to correctly reference this scholarly work, feel free to copy and paste the following:

Robert-Benjamin Illing and Nicole Rosskothen-Kuhl (2012). The Cochlear Implant in Action: Molecular Changes Induced in the Rat Central Auditory System, Cochlear Implant Research Updates, Dr. Cila Umat (Ed.), ISBN: 978-953-51-0582-4, InTech, Available from: http://www.intechopen.com/books/cochlear-implantresearch-updates/the-cochlear-implant-in-action-molecular-changes-induced-in-the-rat-central-auditorysystem

\section{INTECH}

open science | open minds

\section{InTech Europe}

University Campus STeP Ri

Slavka Krautzeka 83/A

51000 Rijeka, Croatia

Phone: +385 (51) 770447

Fax: +385 (51) 686166

www.intechopen.com

\section{InTech China}

Unit 405, Office Block, Hotel Equatorial Shanghai

No.65, Yan An Road (West), Shanghai, 200040, China 中国上海市延安西路65号上海国际贵都大饭店办公楼 405 单元

Phone: +86-21-62489820

Fax: +86-21-62489821 
(C) 2012 The Author(s). Licensee IntechOpen. This is an open access article distributed under the terms of the Creative Commons Attribution 3.0 License, which permits unrestricted use, distribution, and reproduction in any medium, provided the original work is properly cited. 